\title{
A review of the genus Gimnomera Rondani, 1866 (Diptera: Scathophagidae) of Russia
}

\author{
Обзор видов рода Gimnomera Rondani, 1866 \\ (Diptera: Scathophagidae) фауны России
}

\begin{abstract}
A.L. Ozerov

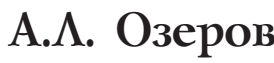

Zoological Museum, Lomonosov Moscow State University, Bol'shaya Nikitskaya 2, Moscow 125009, Russia.

E-mail: ozerov2455@rambler.ru

Зоологический музей, Московский государственный университет им. М.В. Ломоносова, Большая Никитская ул., 2, Москва 125009, Россия.
\end{abstract}

KEY WORDS: Diptera, Scathophagidae, Gimnomera, Russia, review, new species, new synonyms, lectotypes.

КЛЮЧЕВЫЕ СЛОВА: Diptera, Scathophagidae, Gimnomera, Россия, обзор, новые виды, новые синонимы, лектотипы.

ABSTRACT. Flies of the genus Gimnomera Rondani, 1866 of Russia, which includes 19 species, are reviewed. Generic and species descriptions and key for determination of species are given, and data on distributions are summarized. Three species are described as new to science from Asiatic part of Russia: Gimnomera nigricorpus, sp.n., Gimnomera nudipedis, sp.n., and Gimnomera palliseta sp.n. Three new synonyms are proposed: Gimnomera Rondani, $1866=$ Langechristia Ozerov, 1999, syn.n., Gimnomera tibialis (Malloch, 1919) = Gimnomera sibirica (Engelmark, 1999), syn.n.; Gimnomera novgorodovae (Ozerov, 2006) = Gimnomera sorokinae (Ozerov, 2006), syn.n. Lectotypes are designated for Cordylura dorsata Zetterstedt, 1838 and Cordylura pectoralis Zetterstedt, 1838.

PЕЗЮМЕ. Дан обзор двукрылых рода Gimnomera Rondani, 1866 фауны России, включающего 19 видов. Приведены диагноз рода, описания видов и ключ для определения видов рода Gimnomera России, а также суммированы данные по распространению видов рода на территории России. Описаны 3 новых для науки вида из азиатской части России: Gimnomera nigricorpus, sp.n., Gimnomera nudipedis, sp.n. и Gimnomera palliseta, sp.n. Установлены 3 новых синонима: Gimnomera Rondani, 1866 = Langechristia Ozerov, 1999, syn.n.; Gimnomera tibialis (Malloch, 1919) = Gimnomera sibirica (Engelmark, 1999), syn.n.; Gimnomera novgorodovae $($ Ozerov, 2006) $=$ Gimnomera sorokinae (Ozerov, 2006), syn.n. Обозначены лектопипы для двух видов: Cordylura dorsata Zetterstedt, 1838 и Cordylura pectoralis Zetterstedt, 1838.

\section{Introduction}

Gimnomera Rondani, 1866 is not large genus within the family Scathophagidae. The species from the genus Langechristia Ozerov, 1999 (3 species) are also included in the genus Gimnomera.

The division of species in the genera Gimnomera and Langechristia is based on the absence of short erect spinules on anterior margin of pospronotal lobe in Langechristia (Fig. 3) and the presence of these spinules in species of Gimnomera (Fig. 2) [Ozerov, 1999b]. The studied material, however, has shown that the short spinules on anterior margin of pospronotal lobe may be absent in certain species of Gimnomera, in particular in Nearctic Gimnomera incisurata (Malloch, 1920) and Palaearctic Gimnomera albipila (Zetterstedt, 1846).

The genus Gimnomera consists of 25 species distributed in the Northern Hemisphere (5 Nearctic, 20 Palaearctic) [Vockeroth, 1965; Gorodkov, 1986; Šifner, 2008; Ozerov, 2009; Ozerov \& Krivosheina, 2013]. The fauna of Russia includes 16 species [Becker, 1900; Gorodkov, 1970, 1986; Engelmark, 1999; Ozerov, 1999a, 1999b; Ozerov, 2006, 2009; Ozerov \& Barkalov, 2014; Ozerov \& Krivosheina, 2013, 2014], but no general work has been fulfilled.

Very little is known about the biology of Gimnomera. Species of this genus develop in plants from the genus Pedicularis (fam. Scrophulariaceae) and are usually collected at locations where these plants grow.

Larvae of Palaearctic G. tarsea (Fallén, 1819) live in the seed capsules of marsh lousewort (Pedicularis palustris) [Chandler, 1975]. Another species, G. hirta (Hendel, 1930), infests flowers of Pedicularis sceptrum-carolinum [Ryden, 1933]. Larvae of North Ame-

How to cite this article: Ozerov A.L. 2019. A review of the genus Gimnomera Rondani, 1866 (Diptera: Scathophagidae) of Russia // Russian Entomol. J. Vol.28. No.2. P.195-218. doi: 10.15298/rusentj.28.2.15 


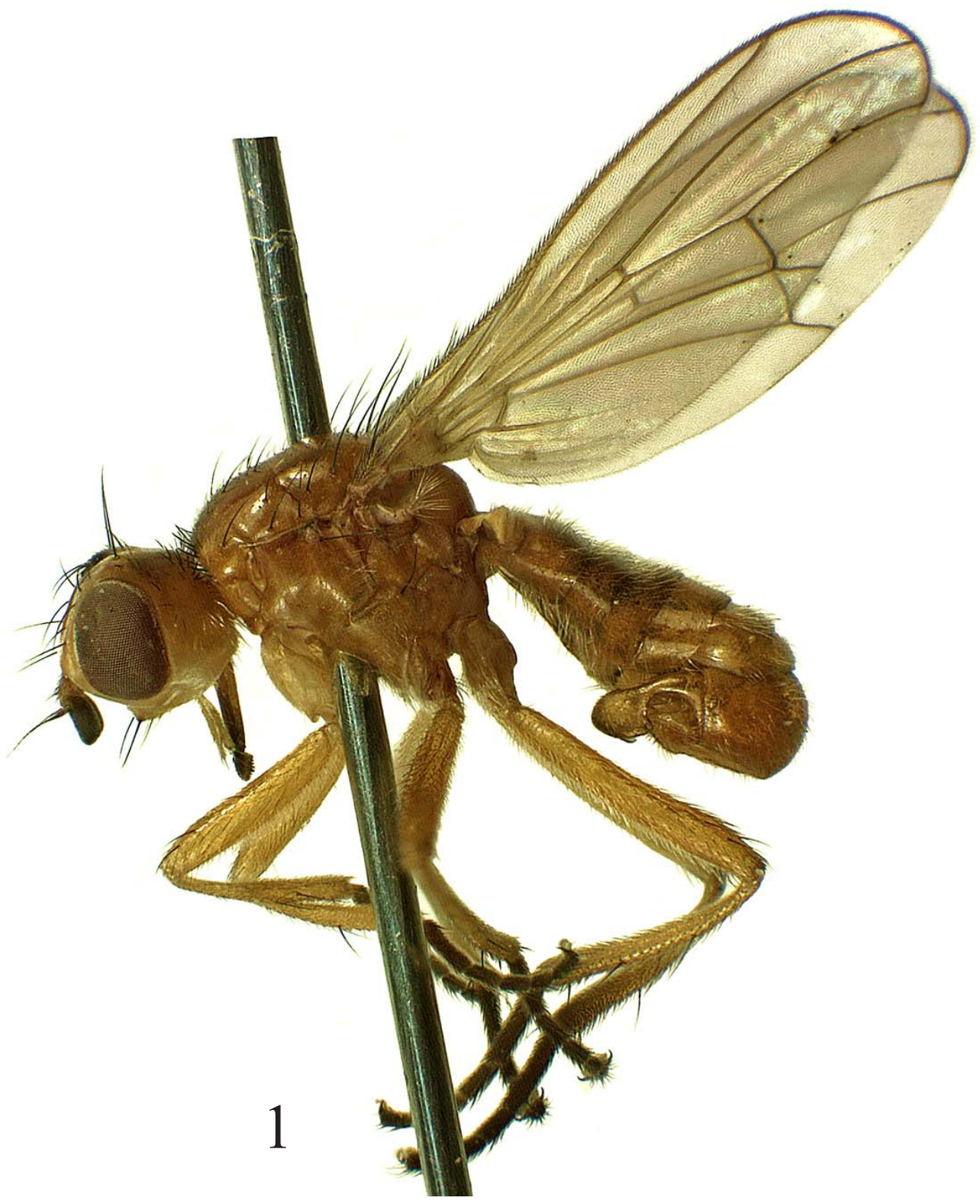

Fig. 1. Gimnomera tarsea (Fallén), male habitus.

Рис. 1. Gimnomera tarsea (Fallén), общий вид самца.

rican $G$. cerea (Coquillett, 1908) feed upon the ovules and capsule of Pedicularis canadensis [Neff, 1968].

There are descriptions of preimaginal species of $G$. tarsea [Chandler, 1975] and G. cerea [Neff, 1968].

\section{Material and methods}

The majority of specimens examined for this study are deposited in the Zoological Museum, Moscow State University, Russia (ZMUM) and Zoological Institute of Russian Academy of Sciences, St. Petersburg, Russia (ZISP). I have also studied some material from the
Canadian National Collection of Insects, Ottawa, Canada (CNC), Museum für Naturkunde der HumboldtUniversität, Berlin, Germany (ZMHB), and Lund University, Lund, Sweden (MZLU).

The majority of original Russian geographical names are given in transliteration, but names of some large geographical regions (e.g. Altai (=Altai Kray + Altai Republic), Krasnoyarsk Krai, North Ossetia-Alania, Primorsky Krai, Sakha Republic (=Yakutia), Zabaykalsky Krai) follow these indicated in Google Earth software. The terminology used in the generic descriptions, species diagnoses, descriptions of the new spe- 
cies, and keys follows McAlpine [1981], Cumming et al. [2009], except that "postpedicel" is used for antennal flagellomere 1 (third antennal segment) [Stuckenberg, 1999].

\section{Taxonomic part}

\section{Gimnomera Rondani, 1866}

Gimnomera Rondani, 1866: 21 (1867: 135). Gender: feminine. Type-species: Cordylura tarsea Fallén, 1819, by original designation.

Kochlearium Strobl, 1894: 79. Nomen nudum.

Cochliarium Becker, 1894: 183. Gender: neuter. Type-species: Cordylura cuneiventris Zetterstedt, 1846, by original designation.

Dasypleuron Malloch, 1919: 79. Gender: neuter. Type-species: Dasypleuron tibialis Malloch, 1919, by original designation.

Paragymnomera Hendel, 1930: 80 [as subgenus of Gymnomera]. Gender: feminine. Type-species: Gymnomera hirta Hendel, 1930 , by original designation.

Rhopochilus Enderlein, 1936: 136. Gender: masculine. Typespecies: Cochliarum lasiostoma Becker, 1894, by monotypy.

Langechristia Ozerov, 1999b: 510. Gender: feminine. Typespecies: Langechristia ziegleri Ozerov, 1999, by original designation - syn.n.

Gymnomera, error

Gimnomera species are small or medium-sized flies (2.4-5.8 mm long) (Fig. 1). Colour varies from yellow to black.

Head. Postcranium covered with black setae in upper third and pale hairs in lower part. 2-3 orbitals, 2-4 frontals, 1 ocellar, 1 postocellar (small or very small, divergent), 1 inner vertical, 1 outer vertical; usually 1 2 pairs of vibrissae present. Postpedicel rounded apically, approximately $1.5-2$ times as long as wide. Arista very short haired on whole length. Palpus filiform, without long apical seta.

Thorax. Anterior margin of postpronotum with or without short erect spinules (Figs 2,3). Dorsocentrals $(0-2)+(1-3)$, intra-alars $(0-1)+(0-1)$, supra-alars $(0$ $1)+(1-2)$, postpronotals $0-2$, notopleurals $1-2$, postalars 1-2. Proepisternum with hairs in anterior or central part, with 1 seta near lower margin. Proepimeron with $0-1$ seta or setula and usually with several hairs. Anepisternum covered with hairs in posterior part, with 1-3 setae near posterior margin. Katepisternum covered with hairs in posterior half and 1 strong seta in upper posterior corner. Anepimeron bare or with several hairs. Postmetacoxal bridge absent. Scutellum with a pair of apical scutellar setae present and a pair of lateral/basal scutellar setae present or absent.

Legs. Fore femur with 2-6 posterodorsal setae. Fore tibia with $0-2$ dorsal/anterodorsal setae, $0-1$ posterodorsal and $0-2$ posterior setae at middle, $0-1$ preapical dorsal, $0-1$ apical anteroventral, $0-1$ apical posteroventral, $0-1$ apical anterodorsal, $0-1$ apical ventral and $0-1$ apical posterior setae. Mid femur with or without rows of anterior and posteroventral setae, with $0-1$ anterior, $0-1$ preapical posterior and $0-1$ preapical posterodorsal setae, in G. ziegleri (Ozerov, 1999) without striking setae. Mid tibia with $0-2$ anterodorsal, $0-1$ posterodorsal, $0-1$ posterior, 1 preapical dorsal setae and a ring of apicals. Hind femur with $0-5$ anterodorsal, 0-4 anteroventral, 0-2 preapical anteroventral, 01 preapical posterior, $0-1$ preapical posterodorsal, $0-1$ preapical anterior setae. Hind femur of G. ziegleri and G. nudipedis, sp.n. (see below) without striking setae. Hind tibia with 1-2 anterodorsal, 0-3 posterodorsal, $0-1$ anteroventral, 1 preapical dorsal setae, also with 1 apical anteroventral and $0-1$ anterodorsal setae.

Wing (Fig. 5) clear or slightly brownish; veins brownish. View $R_{1}$ setulose on apical half of dorsal surface (Fig. 4) or bare. Calypters, margins of calypters, and halteres whitish to blackish.

Abdomen cylindrical. Male sternite 4 rectangular or circular, sternite 5 usually with median lobes (Figs 8 , 10-23), in G. albipila without median lobes, but with long triangular lateral lobes (Fig. 9). Male terminalia (Figs 24-71): epandrium with symmetrical surstyli, incompletely fused to epandrium; surstyli often broaded apically; cerci fused apically or medially forming cercal plate, which different in shape: simple (oval or triangulate), bilobed or trident.

Female ovipositor short, compressed laterally, with proctiger shifted dorsally (Figs 6, 7).

\section{Gimnomera alanica (Ozerov, 1999)}

Figs 8, 24-26.

alanica Ozerov, 1999a: 636 (Cochliarium). Type-locality: RUSSIA: environs of Buron (Russia, North Ossetia-Alania).

MATERIAL. North Ossetia-Alania: environs of Buron (Tsey gorge [ $42.793055^{\circ} \mathrm{N}, 43.922161^{\circ} \mathrm{E}$, alt. $\left.1764 \mathrm{~m}\right]$ ), 5.VII.1990, A.L. Ozerov ( $\sigma^{7}$ holotype, ZMUM).

ADDITIONAL MATERIAL. Armenia: Aragatsoth $\left(40.7166^{\circ} \mathrm{N}\right.$ $\left.44.2666^{\circ} \mathrm{E}\right), 1 \mathrm{~km} \mathrm{~S}$ of Sipan, $2100 \mathrm{~m}, 19 . \mathrm{V} .2012$, A.C. Pont (1 $\sigma^{7}$, ZMUM); Azerbaijan: Bechenekskiy pass $\left(39.5445^{\circ} \mathrm{N} 45.8111^{\circ} \mathrm{E}\right)$, 21VI.1967, V. Richter (1 9 , ZISP).

DESCRIPTION. Male, female. Medium-sized flies (4.6-5.5 mm long).

Head. Frontal vitta from yellow to black, matt; fronto-orbital plate yellow or brownish, whitish dusted. Ocellar triangle black. Face, parafacial and gena yellow to black, whitish dusted. Postcranium from yellow to black. 2 orbitals, $2-3$ frontals, 1 ocellar, 1 small postocellar, 1 inner vertical, 1 outer vertical; usually 2 pairs of vibrissae present. Antenna black. Postpedicel approximately 1.5 times as long as wide. Arista black. Palpus yellow.

Thorax black in ground colour, greyish dusted, anepisternum sometimes partly shining. Scutum densely covered with small yellow hairs, including acrostichal area; dorsocentrals $0+1$, intra-alars absent, supra-alars $(0-1)+1,1$ postpronotal, anterior margin of postpronotum with short erect black spinules, notopleurals 2 , postalars 2. Proepisternum with 1 pale seta near lower margin. Proepimeron with 1 pale seta or setula. Anepisternum with 1 black setae near posterior margin. Anepimeron bare. Scutellum yellow, with a pair of apical scutellar setae.

Legs yellow, but fore femur sometimes darkened and tarsi of all legs blackish. Fore femur with 3-4 posterodorsal setae. Fore tibia with 1 dorsal/anterodor- 

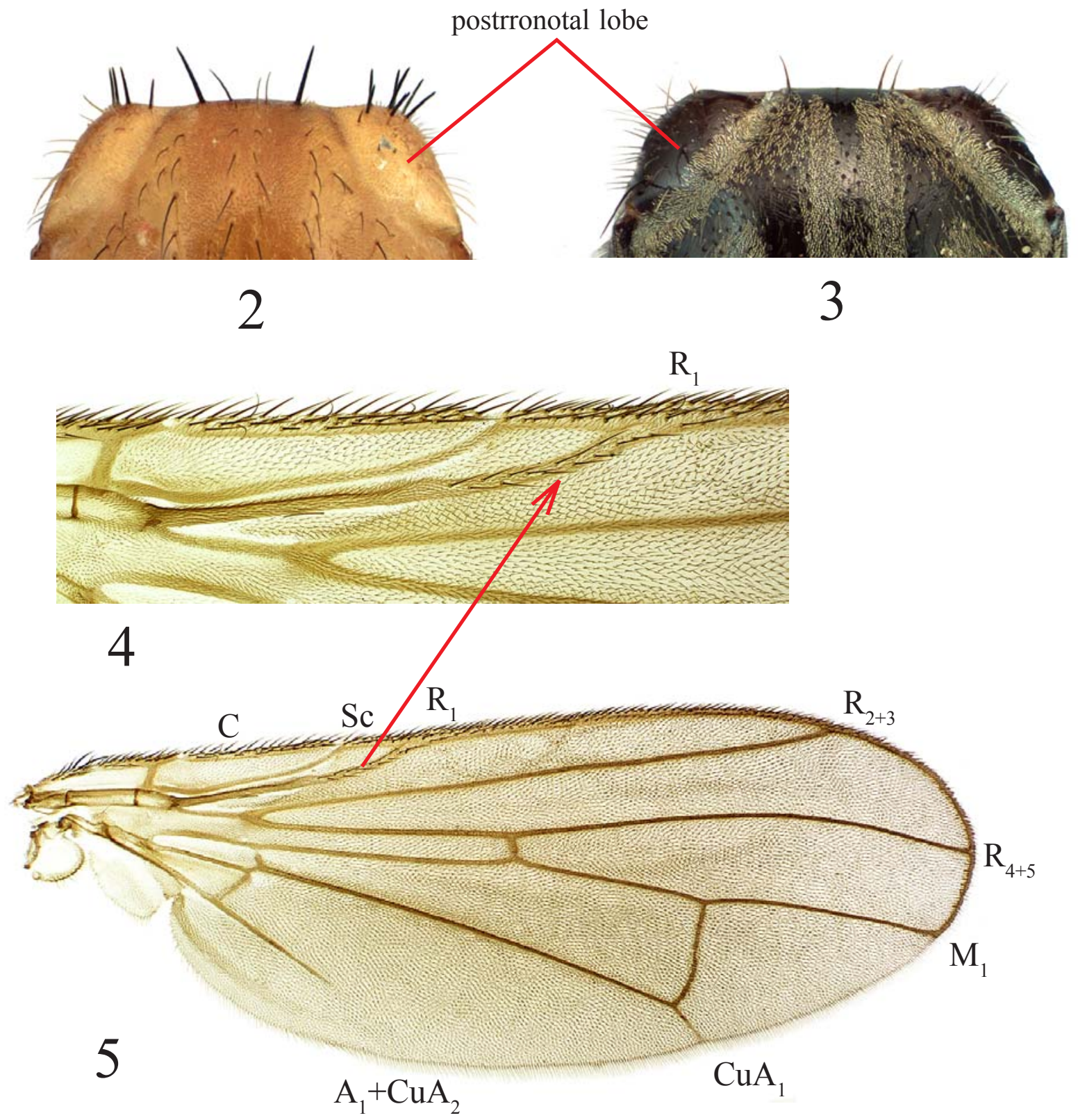

Figs. 2-5. Gimnomera hirta (Hendel) $(2,4,5)$ and Gimnomera ziegleri (Ozerov) (3): 2, 3 - anterior part of scutum, dorsally; 4 fragment of wing; 5 - wing.

Рис. 2-5. Gimnomera hirta (Hendel) (2, 4, 5) и Gimnomera ziegleri (Ozerov) (3): 2, 3 - передняя часть среднеспинки, сверху; 4 фрагмент крыла; 5 - крыло.

sal seta, 1 posterodorsal and 1 posterior setae at middle, 1 preapical dorsal and 1 apical posterior setae. Mid femur with a row of anterior setae in apical half, also with 1 preapical posterior and 1 preapical posterodorsal setae. Mid tibia with 2 anterodorsal in male, 1 anterodorsal and 1 posterior setae in female, also with 1 preapical dorsal seta and a ring of apical setae in both sexes. Hind femur with 3-5 anterodorsal setae in apical half. Hind tibia with 2 anterodorsal, 1 preapical dorsal setae, also with apical anteroventral and anterodorsal setae.
Wing clear or slightly brownish; veins brownish. Vein $\mathrm{R}_{1}$ setulose on apical half of dorsal surface. Calypters, margins of calypters, and halteres whitish or yellowish.

Abdomen yellowish, darkened medially, subshining in male, shining in female; female abdominal tergites narrowly black along posterior margin. Male sternite 4 rectangular, wider than long; sternite 5 with shallow rounded median lobes, carrying spinules (Fig. 8). Epandrium, cercal plate and surstyli as in Figs 24-26.

DISTRIBUTION. Russia: North Ossetia-Alania. Armenia (first record), Azerbaijan (first record). 

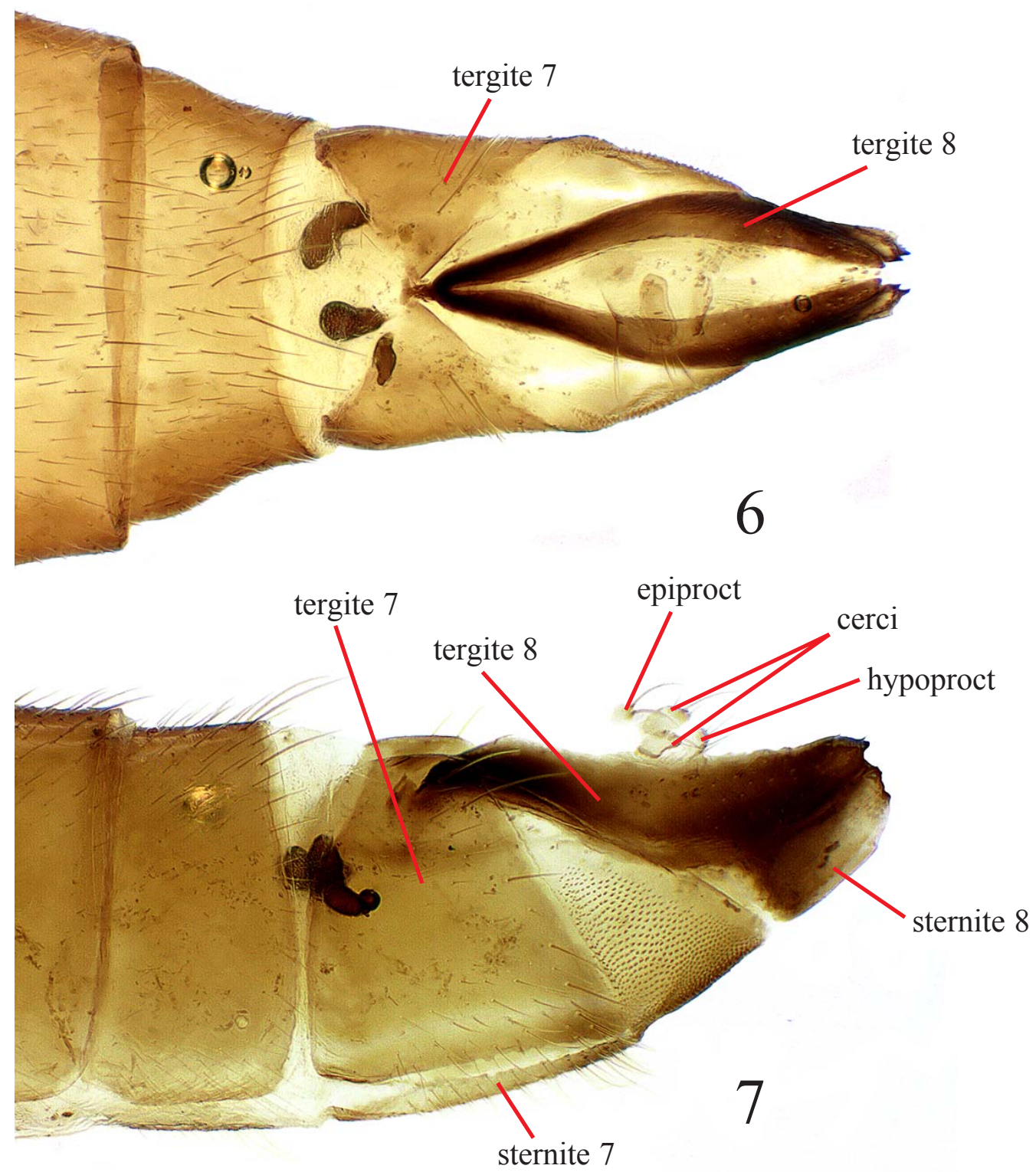

Figs 6-7. Gimnomera hirta (Hendel): 6 - end of female abdomen, dorsal view; 7 - same, lateral view. Pис 6-7. Gimnomera hirta (Hendel): 6 - конец брюшка самки, сверху; 7 - то же, сбоку.

Gimnomera albipila (Zetterstedt, 1846)

Figs 9, 27-29.

albipila Zetterstedt, 1846: 2021 (Cordylura). Type-locality: "Lapponia Lulensi ad Qvickjock" (Sweden).

lucida Becker, 1900: 53 (Microprosopa). Type-locality: "Kantaika" (Khantaika, lower Yenisey, Russia).

The species was recorded for Russia from Siberia without indicating specific locality [Gorodkov, 1970].

MATERIAL. Krasnoyarsk Krai: Kresty $\left(71.9158^{\circ} \mathrm{N}\right.$ 102.1238 E), 11.VII.1976, A. Rasnitsyn, I. Sukacheva (1 $0^{7}$ ZMUM); Tyumen' Oblast: Neroyka (ca. $\left.64.57^{\circ} \mathrm{N} 59.67^{\circ} \mathrm{E}\right), 700$ m, 30.VI.-3.VII.1990, Malozemov (1 $\sigma^{7}$, ZISP); same, 450 m, 2427.VI.1990, Malozemov (1 $\sigma^{7}$, ZISP).
DESCRIPTION. Male. Small-sized flies (2.4-3.5 mm long).

Head. Frontal vitta yellow completely or black in upper half, matt; fronto-orbital plate black in upper half and yellow in lower half or black completely, whitish dusted. Ocellar triangle black. Face yellow or blackish, whitish dusted. Parafacial and gena yellow, whitish dusted. Postcranium black, subshining, but median occipital sclerite greyish dusted. 2-3 orbitals, 3-4 frontals, 1 ocellar, 1 very small postocellar, 1 inner vertical, 1 outer vertical (all setae yellow); $1-2$ pairs of yellow vibrissae present. Scapus and pedicel yellow. 
Postpedicel black, no more than 1.5 times as long as wide. Arista black. Palpus yellow.

Thorax black, greyish dusted, but scutum shining. Acrostichals as hairs in two rows, dorsocentrals $1+2$, intra-alars $1+(0-1)$, supra-alars $1+2,1$ postpronotal, anterior margin of postpronotum without short erect black spinules, notopleurals 2, 1 postalar (all setae yellow). Proepisternum with 1 seta near lower margin. Proepimeron with 1 seta and several hairs. Anepisternum with 2 yellow setae near posterior margin. Anepimeron bare. Scutellum black, shining, with a pair of lateral scutellar and a pair of apical scutellar setae.

Legs yellow completely or slightly darkened. Hairs and setae of all legs yellow. Fore femur with a row of posterodorsal setae. Fore tibia with 1 preapical dorsal seta. Mid femur with $0-1$ preapical posterodorsal seta. Mid tibia with $0-1$ anterodorsal, 1 preapical dorsal setae and a ring of apical setae. Hind femur with $0-2$ anterodorsal setae in apical half. Hind tibia with 1 anterodorsal, 1 preapical dorsal and 1 apical anteroventral setae.

Wing clear; veins brownish. Vein $\mathrm{R}_{1}$ setulose on apical half of dorsal surface. Calypters, margins of calypters, and halteres pale whitish.

Abdomen black, subshining. Male sternite 4 small rectangular, wider than long; sternite 5 with long triangular lateral lobes (Fig. 8). Epandrium, cercal plate and surstyli as in Figs 24-26.

DISTRIBUTION. Russia: Krasnoyarsk Krai, Tyumen' Oblast. — Scandinavia [Šifner, 2008].

\section{Gimnomera amica (Ozerov, 1999)}

amica Ozerov, 1999b: 511 (Langechristia). Type-locality: 30 km SE Chuguyevka $\left(44.05^{\circ} \mathrm{N} 134.2^{\circ} \mathrm{E}\right)$ (Russia, Primorskiy Krai).

This species is known only from the type-locality [Ozerov, 1999b].

DESCRIPTION (translated from description by Ozerov, 1999b: 511). "Female. Frontal vitta yellow; fronto-orbital plate black in upper half and yellow in lower half. Ocellar triangle and upper $3 / 4$ of postcranium black. Face, gena, lower $1 / 4$ of postcranium, palpus and proboscis yellow. Antenna and arista yellow, but darker than face. Apical third of arista darkened. Thorax and abdomen black completely. Legs yellow. Wing slightly brownish; veins brownish. Setae of head black, only vibrissae and inner vertical setae yellow. All setae of thorax yellow, only notopleural and postalar setae black. Abdomen covered with yellowish rare hairs.

Frontal vitta matt, fronto-orbital plate shining. Ocellar triangle shining. Postcranium, face and gena greyish dusted. Scutum shining, only notopleuron and alar area greyish dusted. Scutellum shining. Anepisternum, katepisternum and anepimeron mostly shining. Mediotergite greyish dusted, but shining near abdomen. The rest pleural sclerites of thorax greyish dusted. Abdomen shining.

Frons with 3 frontal and 3 orbital setae. Postpronotum with 2 setae."

Male unknown.

DISTRIBUTION. Russia: Primorskiy Krai.
Gimnomera castanipes (Becker, 1894)

Figs 10, 30-32.

castanipes Becker, 1894: 185 (Cochliarium). Type-locality: "St. Moritz" (Switzerland).

The species was recorded for Russia as G. sibirica (Engelmark, 1999) from Chukotka and Yakutia [Engelmark, 1999] and later from Krasnoyarsk Krai (Taimyr) [Ozerov \& Barkalov, 2014].

MATERIAL. Buryatia: Mondy env. $\left(51.6758^{\circ} \mathrm{N} 100.9925^{\circ} \mathrm{E}\right)$, 20.VII.1965, Gorodkov (1 $\sigma^{7}$, ZISP); Chukotka: Pevek $\left(69.7022^{\circ} \mathrm{N}\right.$

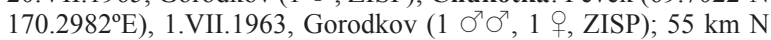
of Egvekinot $\left(66.7956^{\circ} \mathrm{N} 181.00052^{\circ} \mathrm{E}\right), 29$. VII.1963, Gorodkov (2 $\sigma^{7} \sigma^{7}$, ZISP); Krasnoyarsk Krai: Ust'-Tareya $\left(73.2527^{\circ} \mathrm{N}\right.$ $\left.90.5962^{\circ} \mathrm{E}\right), 26$. VII.1967, Gorodkov (21 $\sigma^{7}, 20$ OO. ZISP); the River Pyasina, $90 \mathrm{~km} \mathrm{~S}$ of Ust'-Tareya (ca. $72.3591^{\circ} \mathrm{N} 90.5822^{\circ} \mathrm{E}$ ), 23.VII.1967, K. Gorodkov (1 $\circ$, ZISP); Agapa (ca. $71.412^{\circ} \mathrm{N}$ $\left.89.2689^{\circ} \mathrm{E}\right)$, the River Pyasina, 15.VII.1967, Gorodkov (1 9 , ZISP); Yakutia: Tiksi $\left(71.6351^{\circ} \mathrm{N} 128.8579^{\circ} \mathrm{E}\right), 9 . \mathrm{VII} .,{ }^{10-11 . V I I I .1957,}$ Gorodkov (4 Oج $\sigma^{T}, 5$ 90 , ZISP); same, 20.VII.1971, Chernov (3 $\sigma^{\top} \sigma^{\top}$, ZISP); Sikhtyakh $\left(69.9117^{\circ} \mathrm{N} 125.10415^{\circ} \mathrm{E}\right), 1875$, Chekanovskiy ( $1 \mathrm{O}^{7}$, ZISP); Chai-Tumus Vill. $\left(72.3166^{\circ} \mathrm{N} 125.7333^{\circ} \mathrm{E}\right)$, 28.VII.1957, Gorodkov (1 ア , 1 \%, ZISP).

DESCRIPTION. Male, female. Medium-sized flies (3.2-4.1 mm long).

Head. Frontal vitta from yellow to black, but usually black in upper half and yellow in lower part, matt; fronto-orbital plate from yellow to black, whitish dusted. Ocellar triangle black. Face and parafacial yellow, whitish dusted. Gena from yellow to black, whitish dusted. Postcranium black, usually subshining in upper third and greyish dusted in lower part. 2-3 orbitals, 23 frontals, 1 ocellar, 1 small postocellar, 1 inner vertical, 1 outer vertical; $1-2$ pairs of vibrissae present. Scapus and pedicel brownish; postpedicel black, approximately 1.5 times as long as wide. Arista black. Palpus brownish.

Thorax black, greyish dusted, only scutum with fore shining interrupted stripes (two linear between dorsocental setae and two wide between dorsocentral and supra-alar setae). Dorsocentrals $(0-1)+1$ (presutural small), intra-alars absent, supra-alars $0+2,0-1$ (small) postpronotal, anterior margin of postpronotum with short erect black spinules, notopleurals 2, postalars 2. Proepisternum with 1 seta near lower margin. Proepimeron with 1 seta and several hairs. Anepisternum with 1-2 setae near posterior margin. Anepimeron with several hairs. Scutellum black, with a pair of lateral scutellar and a pair of apical scutellar setae.

Legs from yellow to black, but apex of fore femur and fore tibia always yellow. Fore femur with 2-4 posterodorsal setae. Fore tibia with 1 dorsal/anterodorsal seta and 1 preapical dorsal setae. Mid femur with 1 preapical posterodorsal seta. Mid tibia with 0-1 anterodorsal, 1 preapical dorsal setae and a ring of apical setae. Hind femur with 1-4 anterodorsal and 1-4 anteroventral setae in apical half and $0-1$ preapical anterior seta. Hind tibia with 1-2 anterodorsal, $0-1$ posterodorsal, 1 preapical dorsal setae, also with 1 apical anteroventral seta.

Wing slightly brownish; veins brownish. Vein $\mathrm{R}_{1}$ setulose on apical half of dorsal surface. Calypters, margins of calypters, and halteres from whitish to greyish. 
Abdomen black, usually shining. Male sternite 4 rectangular, wider than long; sternite 5 transverse, with conical median lobes, carrying spinules (Fig. 10). Epandrium, cercal plate and surstyli as in Figs 30-32.

DISTRIBUTION. Russia: Buryatia, Chukotka, Krasnoyarsk Krai, Yakutia. — Central Europe [Šifner, 2008].

\section{Gimnomera cuneiventris (Zetterstedt, 1846)} Figs 11, 33-35.

cuneiventris Zetterstedt, 1846: 2020 (Cordylura). Type-locality: "Lapponia Lulensi; ad Qvickjock in summitate alpis Snjerak" (nr Kvikkjokk, Norrbotten, Sweden).

Noted by Gorodkov from Kola Peninsula [Gorodkov, 1970] and for European part of Russia without indicating specific locality [Gorodkov, 1986], also from Magadan Oblast [Ozerov \& Krivosheina, 2014].

MATERIAL. Chukotka: the upper reaches of the Bol'shaya River $\left(63.0185^{\circ} \mathrm{N} 171.8464^{\circ} \mathrm{E}\right), 23$.VII.1959, Gorodkov (1 $\sigma^{7}$, ZISP); Krasnoyarsk Krai: Khatanga $\left(71.9758^{\circ} \mathrm{N} 102.4824^{\circ} \mathrm{E}\right), 11-$ 12.VII.1970, Zherikhin, Sukacheva (1 $\sigma^{7}$, ZMUM); Tyumen' Oblast: Labytnangi env. $\left(66.6611^{\circ} \mathrm{N} 66.3945^{\circ} \mathrm{E}\right)$, VII.1971, Ol'shvang (2 $\sigma^{7} \sigma^{\top}$, in ZISP); Neroyka (ca. $\left.64.57^{\circ} \mathrm{N} 59.67^{\circ} \mathrm{E}\right), 850 \mathrm{~m}, 24$ 27.VI.1990, Malozemov (1 $\sigma^{7}$, ZISP).

DESCRIPTION. Male. Small-sized flies (2.7-3.1 $\mathrm{mm}$ long).

Head. Frontal vitta from yellow to black, matt; fronto-orbital plate black, whitish dusted. Ocellar triangle black. Face and parafacial from yellow to black, whitish dusted. Gena yellow completely or blackish in anterior half, whitish dusted. Postcranium black, but yellowish along lower margin, usually subshining in upper third and greyish dusted in lower part. 2-3 orbitals, 2 frontals (additionally fronto-orbital plate with a row of small hairs), 1 ocellar, 1 small postocellar, 1 inner vertical, 1 outer vertical; $1-2$ pairs of vibrissae present. Scapus and pedicel dark brown. Postpedicel black, no more than 1.5 times as long as wide. Arista black. Palpus yellow.

Thorax black, greyish dusted. Scutum densely covered with small yellow hairs, including acrostichal area; dorsocentrals $0+1$, intra-alars absent, supra-alars $0+1$, postpronotal absent, anterior margin of postpronotum with short erect black spinules, notopleurals 2, postalars 1-2. Proepisternum with 1 seta near lower margin. Proepimeron with 1 seta and several hairs. Anepisternum with 2 setae near posterior margin. Anepimeron with several hairs. Scutellum black, with a pair of lateral scutellar and a pair of apical scutellar setae.

Legs yellow, only tarsi of all legs darkened. Fore femur with a row of posterodorsal setae. Fore tibia with 1 dorsal/anterodorsal seta, 1 posterior and 1 preapical dorsal setae. Mid femur with 1 preapical posterodorsal seta. Mid tibia with 1 anterodorsal, $0-1$ posterior, 1 preapical dorsal setae and a ring of apical setae. Hind femur with $1-$ 4 anterodorsal setae in apical half and $0-1$ preapical anterior seta. Hind tibia with 1 anterodorsal, 1 preapical dorsal setae, also with 1 apical anteroventral seta.

Wing clear; veins brownish. Vein $\mathrm{R}_{1}$ setulose on apical half of dorsal surface. Calypters, margins of calypters, and halteres pale yellow.
Abdomen black, subshining. Male sternite 4 oval, slightly wider than long; sternite 5 transverse oval, with shallow median lobes, covered with spinules (Fig. 11). Epandrium, cercal plate and surstyli as in Figs 33-35.

DISTRIBUTION. Russia: Chukotka, Magadan Oblast, Kola Peninsula, Krasnoyarsk Krai, Tyumen' Oblast. - Europe [Šifner, 2008].

\section{Gimnomera dorsata (Zetterstedt, 1838)} Figs 12, 36-38.

dorsata Zetterstedt, 1838: 735 (Cordylura). Type-locality: "Lapponia Norvegica ... ad Giebostad Nordlandiae ... Dowre” (Norway). pectoralis Zetterstedt, 1838: 734 (Cordylura). Type-locality: "ad Drivstuen in Dowre... (Lapponia)" (Dovre, Norway).

Noted by Gorodkov [1970] from Kola Peninsula.

MATERIAL. No found material in ZISP and ZMUM.

ADDITIONAL MATERIAL. A female labelled "Giebostad", "Lectotypus Cordylura dorsata Ztt. Designated by J.R. Vockeroth 19" [designation not published] (MZLU). This specimen has been labelled and is herewith designated as lectotype of Cordylura dorsata Zetterstedt. A male labelled "C. dorsata o" (pectoralis Drivst[uen] Lappon Dovre Boh.", "Lectotypus Cordylura pectoralis Ztt. Designated by J.R. Vockeroth 19" [designation not published] has been labelled and is herewith designated as lectotype of Cordylura pectoralis Zetterstedt (MZLU); a female labelled "C. dorsata $q$ (pectoralis Driv (Lap) Dovre", has been labeled as paralectotype (MZLU); both are conspecific with Gimnomera dorsata (Zetterstedt, 1838). "Abisco 7.10" (1 o , 1 \%, ZMHB); "St.Moritz, 26.VII.1914, Oldenberg" (1 ه", ZMHB).

DESCRIPTION. Male, female. Small-sized flies (3.8-4.5 mm long).

Yellow in ground colour; ocellar triangle black; median occipital sclerite brownish; scutum brownish completely or in central part (brownish stripe between postpronotal lobes); anepimeron, katatergite, meron and metepisternum from yellow to brownish; mediotergite blackish; female abdominal tergites narrowly black near posterior margin. Thorax, also male abdomen fine greyish dusted, female abdomen shining. Scutum with fore shining stripes: two thin between dorsocentral lines, two wide between dosocentral and supra-alar lines.

Head with 2 orbital, 2-3 frontal, 1 ocellar, 1 small postocellar, 1 inner vertical, 1 outer vertical setae; 1 pair of vibrissae. Antenna yellow. Postpedicel approximately 2.0 times as long as wide. Arista black. Palpus yellow.

Thorax. Acrostichals as hairs in two rows, dorsocentrals (1-2)+1 (first presutural small), intra-alars absent, supra-alars $1+2,1$ strong postpronotal, anterior margin of postpronotum with short erect black spinules, notopleurals 2, postalars 2. Proepisternum with 1 seta near lower margin. Proepimeron with $0-1$ setula. Anepisternum with 1-2 black setae along posterior margin. Anepimeron bare. Scutellum shining or subshining, with a pair of lateral scutellar and a pair of apical scutellar setae.

Legs. Fore femur with 2-3 posterodorsal setae. Fore tibia with 1-2 dorsal setae, 1 posterodorsal and 1 posterior setae at middle, 1 preapical dorsal and 1 apical posterior setae. Mid femur with a row of anterior setae, also with 1 preapical posterior seta. Mid tibia with 1 posterodorsal, 1 posterior, 1 anterodorsal at middle, with 1 preapical dorsal seta and a ring of apical setae. Hind femur with 2-4 anterior/anterodorsal, 1-2 preapi- 
cal anteroventral setae. Hind tibia with 1 posterodorsal, 2 anterodorsal, 1 preapical dorsal setae, also with 1 apical anteroventral and 1 anterodorsal setae.

Wing clear or slightly brownish; veins brownish. Vein $\mathrm{R}_{1}$ bare. Calypters, margins of calypters, and halteres yellowish.

Abdomen. Male sternite 4 trapezoid; sternite 5 transverse, with angulate median lobes, carrying spinules (Fig. 12). Epandrium, cercal plate and surstyli as in Figs 36-38, cerci bifurcate.

DISTRIBUTION. Russia: Kola Peninsula [Gorodkov, 1970]. — Europe [Šifner, 2008].

\section{Gimnomera hirta (Hendel, 1930)} Figs 2, 4-7, 13, 39-41. den".

hirta Hendel, 1930: 79 (Gymnomera). Type-locality: "Schwe-

The species was recorded for Russia from Taimyr [Ozerov \& Barkalov, 2014] and Amur Oblast [Ozerov \& Krivosheina, 2014].

MATERIAL. Amur Oblast: town Zeya $\left(53.7485^{\circ} \mathrm{N}\right.$ 127.2614 $\left.{ }^{\circ} \mathrm{E}\right), 19$. VI. and 9.VII.1978, 24 and 29.VI.1981, 16 and 6.VII.1982, A. Shatalkin, A. Ozerov (6 $\sigma^{7} \sigma^{7}, 5$ 우, ZMUM); Klimoutsy $\left(51.4701^{\circ} \mathrm{N} 127.5991^{\circ} \mathrm{E}\right), 18$.VI.1959, Borisova ( 1 \% , ZISP); Arkhangelsk Oblast: Nar'yan-Mar env. $\left(67.6428^{\circ} \mathrm{N} 53.1963^{\circ} \mathrm{E}\right)$, 6.VII.2008, A.L. Ozerov (23 $\circ \circ$, ZMUM); Zabaykalsky Krai: Chita $\left(52.0181^{\circ} \mathrm{N} 113.5082^{\circ} \mathrm{E}\right)$, the River Kaydalovka, 4.VII.1912, Valueva ( 1 , ZISP).

DESCRIPTION. Male, female. Medium-sized flies (4.2-5.8 mm long).

Yellow species, only ocellar triangle and female abdominal tergite 8 black. Scutum shining, the rest parts of thorax whitish microtrichose. Abdomen subshining.

Head with 2-3 orbital, 2-3 frontal, 1 ocellar, 1 small postocellar, 1 inner vertical, 1 outer vertical setae; 2 pairs of vibrissae present. Postpedicel approximately 2.0 times as long as wide. Arista brown. Palpus yellow.

Thorax. Acrostichals as hairs in two rows, dorsocentrals $(1-2)+(1-2)$, intra-alars absent, supra-alars $(0$ $1)+2$ (presutural small), postpronotal absent, anterior margin of postpronotum with short erect black spinules, notopleurals 2, postalars 2. Proepisternum with 1 seta near lower margin. Proepimeron with 0-1 seta and several hairs. Anepisternum with 1-2 setae near posterior margin. Anepimeron with several hairs. Scutellum with a pair of lateral scutellar and a pair of apical scutellar setae.

Legs. Fore femur with a row of posterodorsal setae. Fore tibia with 1 anterodorsal, 1 posterodorsal and 1 posterior setae at middle, also with 1 preapical dorsal, 1 apical anterodorsal and 1 apical posterior setae. Mid femur with a row of anterior setae, 1 preapical posterodorsal and 1 preapical posterior setae. Mid tibia with 1 anterodorsal, 1 posterodorsal, 1 preapical dorsal setae and a ring of apical setae. Hind femur with 2-5 anterodorsal setae. Hind tibia with 2 anterodorsal, 1 posterodorsal, 1 preapical dorsal setae, also with 1 apical anteroventral and 1 apical anterodorsal setae.
Wing (Fig. 5) slightly yellowish; veins brownish. Vein $R_{1}$ setulose on apical half of dorsal surface (Fig. 4). Calypters, margins of calypters, and halteres yellowish.

Abdomen. Male sternite 4 trapezoid, wider than long; sternite 5 transverse, with hummock shaped short median lobes, covered with spinules (Fig. 13). Epandrium, cercal plate and surstyli as in Figs 39-41. Ovipositor as in Figs 6, 7.

DISTRIBUTION. Russia: Amur Oblast, Arkhangelsk Oblast, Krasnoyarsk Krai, Zabaikalsky Krai. Scandinavia [Šifner, 2008].

\section{Gimnomera lasiostoma (Becker, 1894)}

Figs 14, 42-44.

lasiostoma Strobl, 1894: 79. Nomen nudum.

lasiostoma Becker, 1894: 184 (Cochliarium). Type-locality: "St. Moritz" (Switzerland).

Reported by Ozerov \& Barkalov [2014] from Taimyr and by Ozerov \& Krivosheina [2014] from Russian Far East.

MATERIAL. Altai: Chikhachev ridge, $2600 \mathrm{~m},\left(49.81^{\circ} \mathrm{N}\right.$ $\left.89.55^{\circ} \mathrm{E}\right)$, A. Barkalov (1 $\left.\sigma^{7}, \mathrm{ZMUM}\right)$; Kosh-Agach env., $\left(50.01^{\circ} \mathrm{N}\right.$

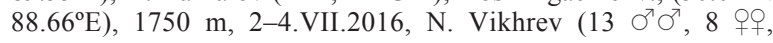
ZMUM); Tashanta $\left(49.7178^{\circ} \mathrm{N} 89.1913^{\circ} \mathrm{E}\right)$, 4.VII.1964, Grunin (1 $\mathrm{O}^{7}$, ZISP); Buryatia: Khargun, $6 \mathrm{~km} \mathrm{E}$ of Kyren $\left(51.6837^{\circ} \mathrm{N}\right.$ $\left.102.1326^{\circ} \mathrm{E}\right)$, Sayan, 11.VII.1965, Gorodkov (1 9 , ZISP); Mondy env. (51.6758 $\left.{ }^{\circ} \mathrm{N} 100.9925^{\circ} \mathrm{E}\right), 18$. VII.1965, Gorodkov (1 ㅇ, ZISP); Irkutsk Oblast: Cherskiy peak $\left(51.5286^{\circ} \mathrm{N} 103.5873^{\circ} \mathrm{E}\right)$, 14.VII.1984, Zlobin (1 9 , ZISP); Krasnodar Krai: Teberda Reserve $\left(43.4438^{\circ} \mathrm{N} 41.7381^{\circ} \mathrm{E}\right), 26 . \mathrm{V} .1964$, Gorodkov (1 9 , ZISP); Krasnoyarsk Krai: Khatanga $\left(71.9758^{\circ} \mathrm{N}, 102.4824^{\circ} \mathrm{E}\right), 11-$ 12.VII.1970, V. Zherikhin, I. Sukatsheva (1 今, ZMUM); the lake Taymyrskoe, west bank W of Baynur-Nehru $\left(\sim 74.1176^{\circ} \mathrm{N}\right.$ $\left.100.9506^{\circ} \mathrm{E}\right), 30$.VII.-7.VIII.1976, A. Rasnitsyn, I. Sukatsheva (1 $\sigma^{7}$, ZMUM); Taimyr Biosphere Reserve, Ary-Mas field station $\left(72.5^{\circ} \mathrm{N} 101.94^{\circ} \mathrm{E}\right), 14 \mathrm{~m}, 12-22 . \mathrm{VII} .2010$, A. Barkalov (2 + \%, ISEA); Magadan Oblast: the River Donyshko $\left(60.41^{\circ} \mathrm{N} 151.52^{\circ} \mathrm{E}\right)$, 17.VII.2014, N. Vikhrev (1 + , ZMUM); Sokol env. $\left(59.92^{\circ} \mathrm{N}\right.$ $\left.150.71^{\circ} \mathrm{E}\right), 11-19$. VII.2014, N. Vikhrev (1 $\sigma^{\top}, 10$ 우, ZMUM); Sakhalin Oblast: Due $\left(50.8243^{\circ} \mathrm{N} 142.1114^{\circ} \mathrm{E}\right), 20$.VI.1914, Belousov (1 $\circ$, ZISP); Yakutia: Olenek $\left(68.5271^{\circ} \mathrm{N} 114.0452^{\circ} \mathrm{E}\right)$, 1874 , Chekanovskiy ( 1 + , ZISP); Nizhneyansk $\left(71.441^{\circ} \mathrm{N}\right.$ 136.1355 ${ }^{\circ}$ ), 31.VII.1974, Gorodkov (1 $\sigma^{7}$, ZISP).

ADDITIONAL MATERIAL. Mongolia: Selenge aimag, 30 km ENE of Dzun-Khira, 6.VIII.1975, Nartshuk (1 9 , ZISP).

DESCRIPTION. Male, female. Small or mediumsized flies (3.8-5.4 mm long).

Colour from yellow to black, tarsi of all legs always blackish.

Head with 3 orbital, 2-4 frontal, 1 ocellar, 1 small postocellar, 1 inner vertical, 1 outer vertical setae; 2 pairs of vibrissae. Postpedicel approximately 1.5 times as long as wide. Antenna black. Arista black. Palpus yellow.

Thorax. Scutum densely covered with small yellow hairs, including acrostichal area; dorsocentrals $0+1$, intra-alars absent, supra-alars $0+1$, postpronotal absent, anterior margin of postpronotum with short erect black spinules, notopleurals 2, postalars 2. Proepisternum with 1 seta near lower margin. Proepimeron with 1 seta and with several small hairs. Anepisternum with 1-2 black setae near posterior margin. Anepimeron with several small hairs. Scutellum with a pair of apical scutellar setae. 

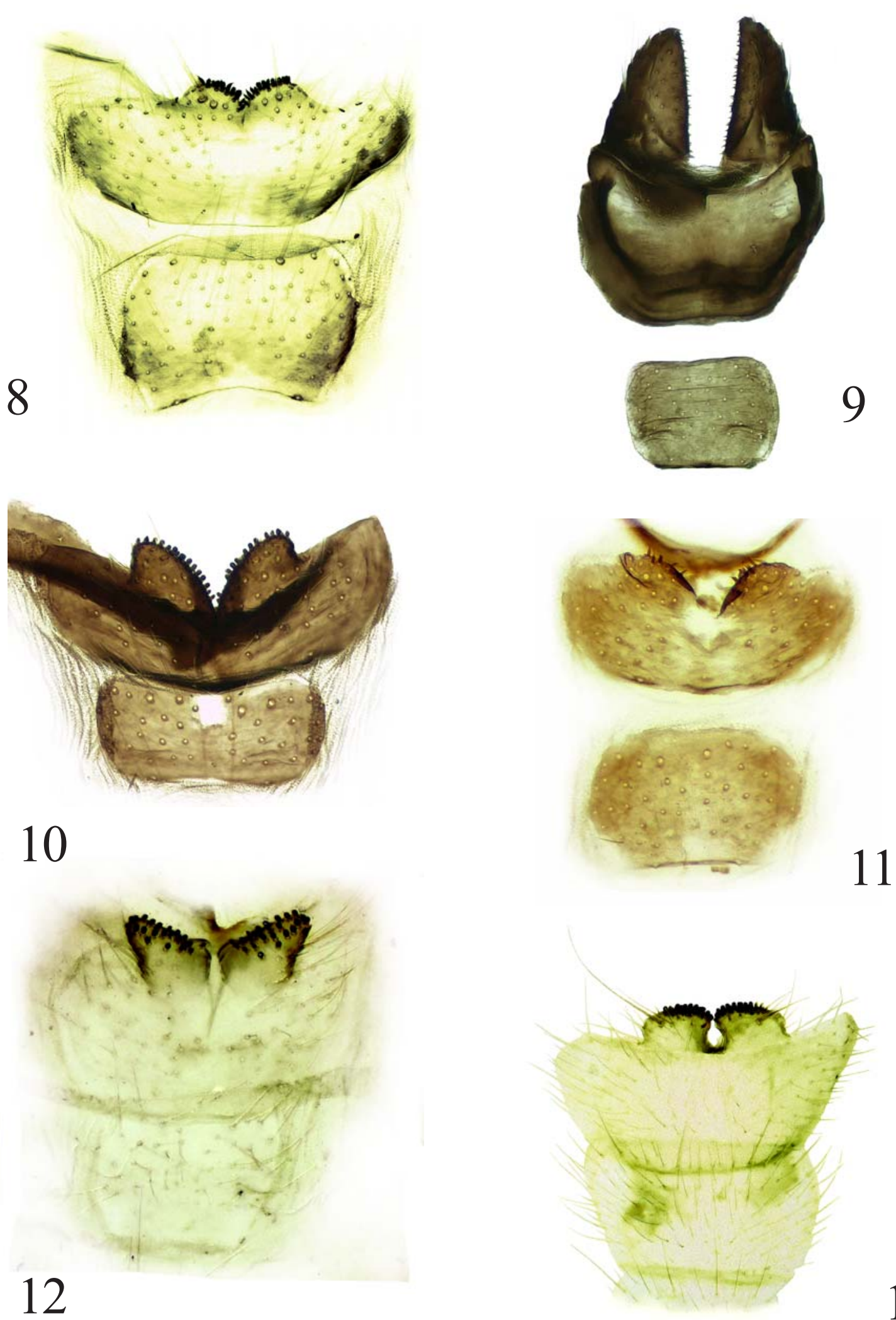

13

Figs 8-13. Male sternites 4 (lower) and 5 (upper) of Gimnomera: 8 - G. alanica (Ozerov); 9 - G. albipila (Zetterstedt); $10-$ G. castanipes (Becker); 11 - G. cuneiventis (Zetterstedt); $12-$ G. dorsata (Zetterstedt); 13 - G. hirta (Hendel).

Рис. 8-13. Стерниты 4 (внизу) и 5 (вверху) самца Gimnomera: 8 - G. alanica (Ozerov); 9 — G. albipila (Zetterstedt); $10-G$. castanipes (Becker); $11-$ G. cuneiventis (Zetterstedt); $12-$ G. dorsata (Zetterstedt); 13 - G. hirta (Hendel). 

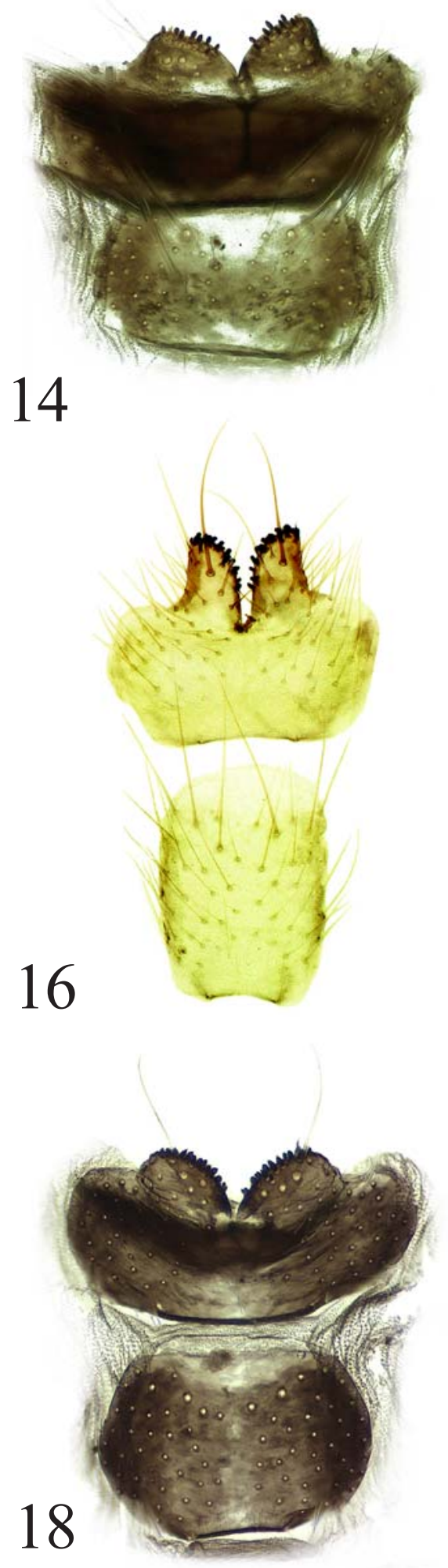

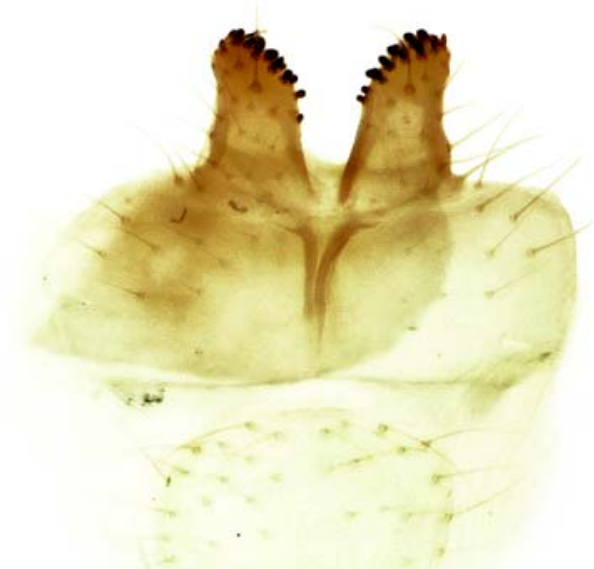

15

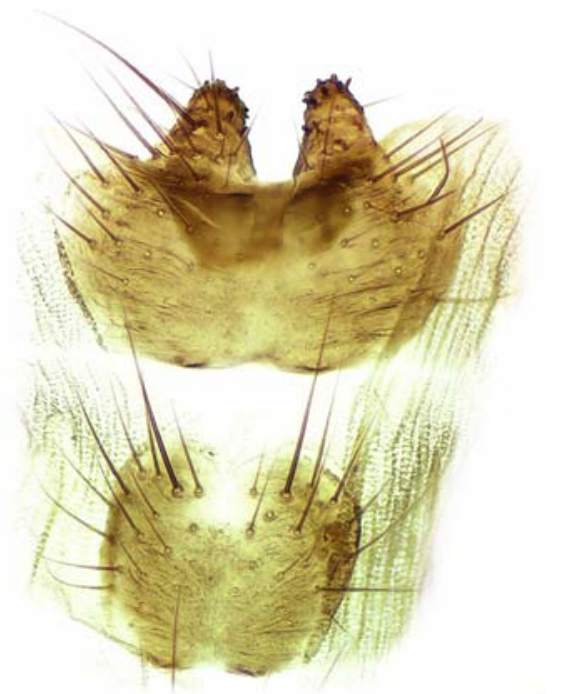

17

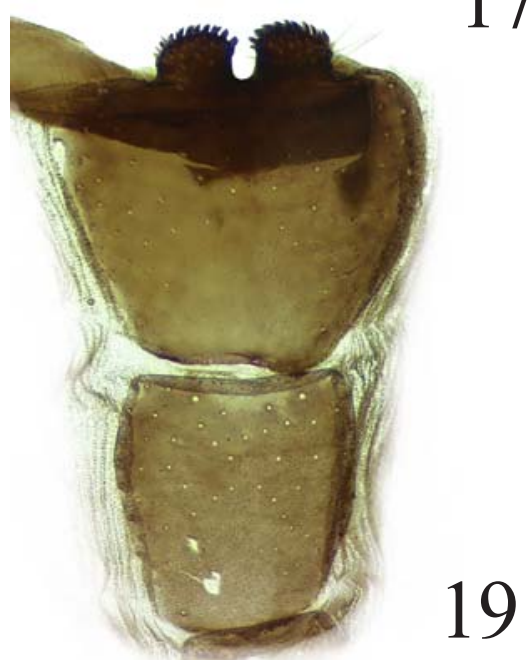

Figs 14-19. Male sternites 4 (lower) and 5 (upper) of Gimnomera: $14-$ G. lasiostoma (Becker); 15 - G. mellina (Becker); $16-G$. montana Ozerov et Krivosheina; 17 - G. nigricorpus sp.n.; $18-$ G. novgorodovae (Ozerov); $19-$ G. nudipedis sp.n.

Рис. 14-19. Стерниты 4 (внизу) и 5 (вверху) самцов Gimnomera: 14 - G. lasiostoma (Becker); 15 - G. mellina (Becker); $16-$ G. montana Ozerov et Krivosheina; $17-$ G. nigricorpus sp.n.; $18-$ G. novgorodovae (Ozerov); $19-$ G. nudipedis sp.n. 

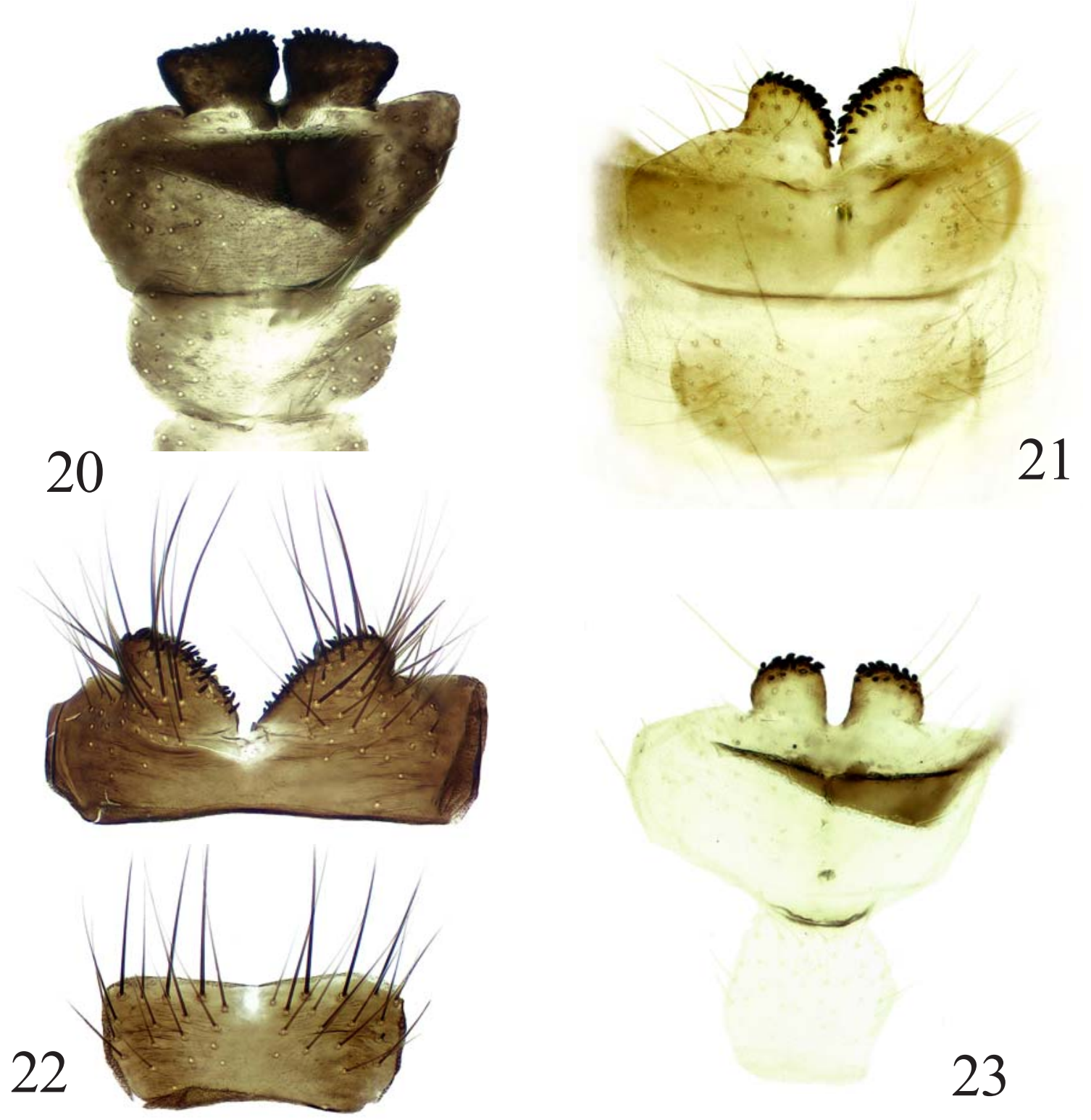

Figs 20-23. Male sternites 4 (lower) and 5 (upper) of Gimnomera: $20-$ G. palliseta sp.n.; 21 - G. tarsea (Fallén); $22-$ G. tibialis (Malloch); $23-$ G. ziegleri (Ozerov).

Рис. 20-23. Стерниты 4 (внизу) и 5 (вверху) самцов Gimnomera: $20-$ G. palliseta sp.n.; $21-$ G. tarsea (Fallén); $22-G$. tibialis (Malloch); 23 - G. ziegleri (Ozerov).

Legs. Fore femur with 2-4 posterodorsal setae in apical half. Fore tibia with 1 dorsal/anterodorsal seta, and $1-2$ posterior setae at middle, 1 preapical dorsal and 1 apical posterior setae. Mid femur with a row of anterior setae in apical half, also with 1 preapical posterior and 1 preapical posterodorsal setae. Mid tibia with 1 anterodorsal, $0-1$ posterior setae at middle, also with 1 preapical dorsal seta and a ring of apical setae. Hind femur with 2-4 anterodorsal setae in apical half. Hind tibia with 2 anterodorsal and 1 preapical dorsal setae, also with 1 apical anteroventral and 1 apical anterodorsal setae.
Wing clear; veins brownish. Vein $\mathrm{R}_{1}$ setulose on apical half of dorsal surface. Calypters, margins of calypters, and halteres whitish or yellowish.

Abdomen. Male sternite 4 rectangular, about 2 times as wide as long; sternite 5 transverse, with shallow rounded median lobes, carrying spinules (Fig. 15). Epandrium, cercal plate and surstyli as in Figs 4547.

DISTRIBUTION. Russia: Altay, Buryatia, Irkutsk Oblast, Krasnodar Krai, Krasnoyarsk Krai, Magadan Oblast, Sakhalin Oblast, Yakutia. - Central Europe [Šifner, 2008], Mongolia (first record). 
Gimnomera mellina (Becker, 1900)

Figs 15, 45-47.

mellina Becker, 1900: 57 (Gymnomera). Type-locality: Dudinka (ca. $69.3998^{\circ} \mathrm{N} 86.1836^{\circ} \mathrm{E}$ ) (Russia, Krasnoyarsk Krai).

This species was noted for Russia from Krasnoyarsk Krai [Becker, 1900; Ozerov \& Krivosheina, 2013].

MATERIAL. Irkutsk Oblast: Cherskiy peak $\left(51.5286^{\circ} \mathrm{N}\right.$ $103.5873^{\circ}$ E), 14.VII.1984, Zlobin (1 + , ZISP); Krasnoyarsk Krai: Agapa (ca. $71.412^{\circ} \mathrm{N} 89.2689^{\circ} \mathrm{E}$ ), the River Pyasina, $15-$ 18.VII.1967, Gorodkov (9 $\sigma^{7} \sigma^{7}, 3$ 우, ZISP); Turuchansk (65.7972 $\left.{ }^{\circ} \mathrm{N} 87.9586^{\circ} \mathrm{E}\right), 27$. VI.1967, Gorodkov (2 $9+$, ZISP).

DESCRIPTION. Male, female. Small or mediumsized flies (3.5-4.1 mm long).

Yellow species, only ocellar triangle black. Scutum shining, the rest parts of thorax and abdomen subshining.

Head with 2 orbital, 2 frontal, 1 ocellar, 1 small postocellar, 1 inner vertical, 1 outer vertical setae; 1 pair of vibrissae. Postpedicel approximately 2.0 times as long as wide. Arista black. Palpus yellow.

Thorax. Acrostichals as small hairs in two rows, dorsocentrals $2+2$ (anterior margin of scutum additionally with a pair of erect black setae), intra-alars absent, supra-alars 1 (very small)+2, postpronotal lobe anteriorly with short erect spinules, but without another setae, notopleurals 2, postalars 2. Proepisternum with 1 seta near lower margin. Proepimeron with 1 seta and sometimes with several small hairs. Anepisternum with 1-2 black setae near posterior margin. Anepimeron without hairs. Scutellum with a pair of apical scutellar setae.

Legs. Fore femur with 3-4 posterodorsal setae in apical half. Fore tibia with 1 dorsal/anterodorsal seta, 1 posterodorsal and 1 posterior setae at middle, 1 preapical dorsal and apical posterior setae. Mid femur with a row of anterior setae in apical half, also with 1 preapical posterior and 1 preapical posterodorsal setae. Mid tibia with 1 anterodorsal, 1 posterodorsal, 0-1 posterior setae, also with 1 preapical dorsal seta and a ring of apical setae. Hind femur with 2-4 anterodorsal setae in apical half. Hind tibia with 1-2 anterodorsal, 1 anteroventral, 1 preapical dorsal setae, also with 1 apical anteroventral and 1 apical anterodorsal setae.

Wing clear; veins brownish. Vein $\mathrm{R}_{1}$ bare. Calypters, margins of calypters, and halteres whitish or yellowish.

Abdomen. Male sternite 4 circular; sternite 5 transverse, with long median lobes, covered with spinules (Fig. 15). Epandrium, cercal plate and surstyli as in Figs 45-47.

DISTRIBUTION. Russia: Irkutsk Oblast, Krasnoyarsk Krai.

Gimnomera montana Ozerov et Krivosheina, 2013 Figs 16, 48-50.

montana Ozerov et Krivosheina, 2013: 2 (Gimnomera). Typelocality: range Bakhty Laparyrag $\left(42.9383^{\circ} \mathrm{N} 44.2872^{\circ} \mathrm{E}\right), 1770 \mathrm{~m}$ (Russia, North Ossetia-Alania).

The species was recorded for Russia from North Ossetia-Alania [Ozerov \& Krivosheina, 2013].
MATERIAL. Krasnodar Krai: Teberda Reserve $\left(43.4438^{\circ} \mathrm{N}\right.$ $\left.41.7381^{\circ} \mathrm{E}\right), 9$. VI.1964, Gorodkov (1 9 , ZISP); Lago-Naki $\left(44.0586^{\circ} \mathrm{N}\right.$ $\left.40.0207^{\circ} \mathrm{E}\right), 2100 \mathrm{~m}, 27$. VII.2000, Kustov (2 $\sigma^{7} \sigma^{7}$, ZISP).

ADDITIONAL MATERIAL. Georgia: Kobi $\left(42.5594^{\circ} \mathrm{N}\right.$ 44.5117 ${ }^{\circ}$ E), 14.VII.1925, Kirichenko (1 $\sigma^{7}$, ZMUM); Armenia: Elenovka (now $=$ Sevan) $\left(40.5487^{\circ} \mathrm{N} 44.9574^{\circ} \mathrm{E}\right), 24$. V.1902, Elachich Klemant (1 $\sigma^{7}$, ZISP); Lori, the River Chichkhan near Geghasar $\left(40.85^{\circ} \mathrm{N} 44.20^{\circ} \mathrm{E}\right), 1600 \mathrm{~m}, 22 . V .2012$, A.C. Pont (1 $\sigma^{7}$, ZISP).

DESCRIPTION. Male, female. Small-sized flies (4.0-5.2 mm long).

Yellow in ground colour; ocellar triangle black; scutum yellow completely or brownish in central part, or with black stripe between dorsocental setae; female abdominal tergites narrowly black near posterior margin. Head and thorax, also male abdomen fine greyish dusted, female abdomen shining. Legs yellow.

Head with 2 orbital, 2 frontal, 1 ocellar, 1 postocellar, 1 inner vertical, 1 outer vertical setae; 1 pair of vibrissae. Antenna yellow. Postpedicel approximately 2.0 times as long as wide. Arista black. Palpus yellow.

Thorax. Acrostichals as hairs in two rows, dorsocentrals $2+2$ (anterior margin of scutum also with a pair of erect black setae), intra-alars absent, supra-alars $1+2$, 1 long postpronotal, anterior margin of postpronotum with short erect black spinules, notopleurals 2 , postalars 2. Proepisternum with 1 seta near lower margin. Proepimeron with $0-1$ seta and sometimes with several small hairs. Anepisternum with 2-3 black setae along posterior margin. Anepimeron without hairs. Scutellum shining or subshining, with a pair of basal scutellar and a pair of apical scutellar setae.

Legs. Fore femur with 4-6 posterodorsal setae. Fore tibia with 1 dorsal seta at middle, 1 posterodorsal and 1 posterior setae, 1 preapical dorsal and apical posterior setae. Mid femur with a row of anterior and a row of posteroventral setae, also with 1 preapical posterior and $0-1$ preapical posterodorsal setae. Mid tibia with 1 posterodorsal, 1 posterior, 1 anterodorsal at middle, 1 preapical dorsal setae and a ring of apical setae. Hind femur with a row of anterior setae, also with 1 preapical posterior and $0-1$ preapical posterodorsal setae. Hind tibia with 1 posterodorsal, 2 anterodorsal, 1 preapical dorsal, 1 apical anteroventral and 1 apical anterodorsal setae.

Wing clear, with brownish veins. Vein $\mathrm{R}_{1}$ bare or with 1-4 setulae on apical half of dorsal surface. Calypters, margins of calypters, and halteres yellowish.

Abdomen. Male sternite 4 rectangular, about 1.5 times as long as wide; sternite 5 transverse, with long median lobes, carrying spinules (Fig. 16). Epandrium, cercal plate and surstyli as in Figs 48-50, cerci as wide as long.

DISTRIBUTION. Russia: Krasnodar Krai, North Ossetia-Alania. - Armenia and Georgia [Ozerov \& Krivosheina, 2013], Iran [Khaghaninia \& Gharajedaghi, 2014].

\section{Gimnomera nigricorpus Ozerov, sp.n.} Figs 17, 51-53.

MATERIAL. Holotype $\sigma^{r}$, RUSSIA: Krasnoyarsk Krai: Taimyr, Agapa (ca. $71.412^{\circ} \mathrm{N} 89.2689^{\circ} \mathrm{E}$ ), the River Pyasina, 14.VII.1967, Gorodkov (ZISP). Paratypes: same labels (2 $\sigma^{7} \sigma^{\top}$, 
ZMUM); Altai: Aktash env. $\left(50.326^{\circ} \mathrm{N} 87.739^{\circ} \mathrm{E}\right), 2600 \mathrm{~m}$ 6.VII.2016, N. Vikhrev (1 $\sigma^{7}, 1$, ZMUM); Chukotka: Shmidt $\left(68.8703^{\circ} \mathrm{N} 179.3744^{\circ} \mathrm{W}\right), 11$.VII.1971, Gorodkov (1 9 , ZISP).

DESCRIPTION. Male, female. Small-sizes flies (3.2-3.5 mm long).

Black in ground colour; frontal vitta dark brownish; scutum fine greyish dusted completely or with fore shining stripes; anepisternum mostly shining; apical part of all femora and all tibiae yellow; abdomen fine greyish dusted; antenna black, but scapus brownish.

Head with 2-3 orbital, 3 frontal, 1 ocellar, 1 small postocellar, 1 inner vertical, 1 outer vertical setae; 1 pair of vibrissae. Postpedicel approximately 1.5 times as long as wide. Arista black. Palpus brown.

Thorax. Scutum covered with rare small hairs; acrostichals as hairs in two rows, dorsocentrals $2+1$ (first presutural may be small), intra-alars absent, supra-alars $1+2$, 1 strong postpronotal, anterior margin of postpronotum with short erect black spinules, notopleurals 2, postalars 2. Proepisternum with 1 seta near lower margin. Proepimeron with 1 seta and with several small hairs. Anepisternum with 1-2 black setae near posterior margin. Anepimeron bare. Scutellum with a pair of apical scutellar setae.

Legs. Fore femur with a row of posterodorsal setae. Fore tibia with 1 dorsal/anterodorsal seta, and 1 posterior setae at middle, 1 preapical dorsal and apical posterior setae. Mid femur with a row of anterior setae, also with 1 preapical posterodorsal seta. Mid tibia with 1 anterodorsal, 1 posterodorsal setae at middle, also with 1 preapical dorsal seta and a ring of apical setae. Hind femur with a row of anterodorsal setae. Hind tibia with 2 anterodorsal, $0-1$ posterodorsal, 1 preapical dorsal, 1 apical anteroventral and 1 apical anterodorsal setae.

Wing clear; veins brownish. Vein $\mathrm{R}_{1}$ bare. Calypters and halteres whitish; margins of calypters blackish.

Abdomen. Male sternite 4 circular; sternite 5 transverse, with moderate conical median lobes, covered with spinules and setae (Fig. 17); epandrium, cercal plate and surstyli as in Figs 51-53, cercal plate short and wide.

DISTRIBUTION. Russia: Altai, Chukotka, Krasnoyarsk Krai.

\section{Gimnomera novgorodovae (Ozerov, 2006)} Figs 18, 54-56.

novgorodovae Ozerov, 2006: 334 (Cochliarium). Type-locality: "[Altai, plateau Ukok, lakes Kal'dzin-Kul' and Kal'dzin-Kul' Bas, $\left.2400 \mathrm{~m}\left(49^{\circ} 19^{\prime} \mathrm{N}, 87^{\circ} 26^{\prime} \mathrm{E}\right)\right]^{\prime \prime}$ (Russia).

sorokinae Ozerov, 2006: 335 (Cochliarium). Type-locality: “[Altai, plateau Ukok, lakes Kal'dzin-Kul' and Kal'dzin-Kul' Bas, $\left.2400 \mathrm{~m}\left(49^{\circ} 19^{\prime} \mathrm{N}, 8^{\circ} 26^{\prime} \mathrm{E}\right)\right]^{\prime \prime}$ (Russia) — syn.n.

The species was recorded for Russia from Altai only [Ozerov, 2006].

MATERIAL. Altai: Seminsky pass, $\left(51.06^{\circ} \mathrm{N} 85.59^{\circ} \mathrm{E}\right), 1650$ m, 27-30.VI.2016, N. Vikhrev (1 ऽ', ZMUM); Kurayskiy ridge (50.33 $\left.{ }^{\circ} \mathrm{N} 87.76^{\circ} \mathrm{E}\right), 2600-2700 \mathrm{~m}, 3$. VII.2008, A. Barkalov (2 $\sigma^{7} \sigma^{7}$, ZMUM); Krasnoyarsk Krai: Khatanga $\left(71.9758^{\circ} \mathrm{N}, 102.4824^{\circ} \mathrm{E}\right)$, 11-12.VII.1970, V. Zherikhin, I. Sukatsheva (1 $\sigma^{7}$, ZMUM); Dudinka $\left(69.4042^{\circ} \mathrm{N} 86.1822^{\circ} \mathrm{E}\right), 3$.VII.1967, Gorodkov (1 + , ZISP).
DESCRIPTION. Male. Medium-sized flies (3.8$5.5 \mathrm{~mm}$ long).

Head. Frontal vitta from reddish-yellow to black, matt; fronto-orbital plate black, whitish dusted. Ocellar triangle black. Face, parafacial and gena from yellow to black, whitish dusted. Postcranium black, subshining, but median occipital sclerite greyish dusted. 2-3 orbitals, 2 frontals, 1 ocellar, 1 very small postocellar, 1 inner vertical, 1 outer vertical; 2 pairs of vibrissae present. Antenna black. Postpedicel no more than 1.5 times as long as wide. Arista black. Palpus from yellow to blackish.

Thorax black, greyish dusted, but scutum, anepisternum, katepisternum, also anepimeron in anterior half shining. Scutum densely covered with small yellow hairs, including acrostichal area; dorsocentrals $0+1$, intra-alars absent, supra-alars $0+1$, postpronotal absent, anterior margin of postpronotum with short erect black spinules, 1 notopleural, postalars 2. Proepisternum with 1 seta near lower margin. Proepimeron with 1 seta and several hairs. Anepisternum with 2 setae near posterior margin. Anepimeron with several hairs. Scutellum black, shining, with a pair of lateral scutellar and a pair of apical scutellar setae.

Legs. Femora blackish in ground colour; tibiae of fore and mid legs yellow; hind tibia yellow or brownish; tarsi of all legs blackish. Fore femur with a row of posterodorsal setae. Fore tibia with 1 dorsal/anterodorsal seta, 1 posterior seta at middle, 1 preapical dorsal and 1 apical posterior setae. Mid femur with 2 posteroventral setae basally and 1 preapical posterodorsal seta. Mid tibia with 1 anterodorsal, 1 preapical dorsal setae and a ring of apical setae. Hind femur with 2-4 anterodorsal setae in apical half. Hind tibia with 1-2 anterodorsal, 1 preapical dorsal setae, also with 1 apical anteroventral seta.

Wing slightly brownish; veins brownish. $\mathrm{R}_{1}$ setulose on apical half of dorsal surface. Calypters, margins of calypters, and halteres pale yellow.

Abdomen black, subshining. Male sternite 4 circular; sternite 5 transverse, with shallow rounded median lobes, carrying spinules (Fig. 18). Epandrium, cercal plate and surstyli as in Figs 54-56.

DISTRIBUTION. Russia: Altai, Krasnoyarsk Krai.

\section{Gimnomera nudipedis Ozerov, sp.n.} Figs 19, 57-59.

MATERIAL. Holotype $\sigma^{7}$, RUSSIA: Krasnoyarsk Krai: Taimyr, Agapa (ca. $71.412^{\circ} \mathrm{N} 89.2689^{\circ} \mathrm{E}$ ), the River Pyasina, 14.VII.1967, Gorodkov (ZISP). Paratypes: Yakutia: Tiksi $\left(71.6351^{\circ} \mathrm{N} 128.8579^{\circ} \mathrm{E}\right), 9$.VII.1957, Gorodkov (1 $\sigma^{7}$, ZISP); Stolb Is. $\left(72.3956^{\circ} \mathrm{N} 126.6588^{\circ} \mathrm{E}\right)$, the Lena River delta, 25.VII.1957, Gorodkov (1 $\sigma^{7}$, ZMUM).

DESCRIPTION. Male. Small-sized flies (3.2-3.6 mm long).

Black in ground colour; frontal vitta yellow in lower half or third. Scutum fine greyish dusted completely or partly shining. Anepimeron with shining spot anteriorly. Abdomen fine greyish dusted. Legs black in ground colour, tibiae from black to yellowish. 
Head with 3 orbital, 3-4 frontal, 1 ocellar, 1 small postocellar, 1 inner vertical, 1 outer vertical setae; 2 pairs of vibrissae present. Antenna black. Postpedicel about 1.5 times as long as wide. Arista black. Palpus brownish.

Thorax. Scutum densely covered with small yellow hairs, including acrostichal area; dorsocentrals $2+3$, intra-alars absent, supra-alars $1+2,1$ postpronotal, anterior margin of postpronotum with short erect black spinules, notopleurals 2, postalars 2. Proepisternum with 1 seta near lower margin. Proepimeron with 1 seta and with several small hairs. Anepisternum with 1-2 black setae along posterior margin. Anepimeron with several hairs. Scutellum subshining, with a pair of lateral scutellar and a pair of apical scutellar setae.

Legs. Fore femur with 2-3 small posterodorsal setae. Fore tibia with 1 preapical dorsal, 1 apical anteroventral and 1 apical posterovental setae. Mid femur with 1 small preapical posterodorsal and 1 small preapical posterior setae. Mid tibia with 1 preapical dorsal seta and a ring of apical setae. Hind femur without distinct setae. Hind tibia with 1 preapical dorsal and 1 apical anteroventral setae.

Wing clear or slightly brownish; veins brownish. Vein $\mathrm{R}_{1}$ bare. Calypters, margins of calypters, and halteres yellowish.

Abdomen. Male 4 rectangular, about 1.5 times as long as wide; sternite 5 about as long as wide, with short hummock shaped median lobes, covered with spinules (Fig. 19). Epandrium, cercal plate and surstyli as in Figs 57-59.

DISTRIBUTION. Russia: Krasnoyarsk Krai, Yakutia.

\section{Gimnomera palliseta Ozerov, sp.n.} Figs 20, 60-62.

MATERIAL. Holotype $\sigma^{7}$, RUSSIA: Magadan Oblast, Sokol env. $\left(59.92^{\circ} \mathrm{N} 150.71^{\circ} \mathrm{E}\right), 11-19 . \mathrm{VII} .2014, \mathrm{~N}$. Vikhrev (ZMUM) Paratypes: same labels ( $3 \bigcirc^{7} \sigma^{7}, 7$ 우, ZMUM); Krasnoyarsk Krai: Dudinka $\left(69.4042^{\circ} \mathrm{N} 86.1822^{\circ} \mathrm{E}\right)$, 3.VII.1967, Gorodkov (1 $0^{7}$, ZISP); Irkutsk Oblast: Ust'-Kut $\left(56.7662^{\circ} \mathrm{N} 105.6534^{\circ} \mathrm{E}\right)$, 8.VI.1957, Gorodkov (1 $0^{7}$, ZISP).

DESCRIPTION. Male, female. Medium-sized flies (3.8-4.3 mm long).

Head. Frontal vitta from yellow to black, matt; fronto-orbital plate from yellow to black, whitish dusted. Ocellar triangle black. Face, parafacial and gena from yellow to black, whitish dusted. Postcranium black completely or brownish partly, greyish dusted. 3 orbitals, 2-3 frontals, 1 ocellar, 1 small postocellar, 1 inner vertical, 1 outer vertical (all setae yellow); 1 pair of yellow vibrissae present. Scapus and pedicel brownish; postpedicel black, approximately 1.5 times as long as wide. Arista black. Palpus black.

Thorax from brownish to black, greyish dusted, only scutum mostly shining and anepisternum with shining spot anteriorly. Scutum densely covered with small yellow hairs, including acrostichal area; dorsocentrals $0+1$, intra-alars absent, supra-alars $(0-1)+1$, postpronotum with 1 setula, anterior margin of postpronotum with short erect black spinules, notopleurals 2 , postalars 2. Proepisternum with 1 pale seta near lower margin. Proepimeron with 1 pale seta or setula. Anepister- num with 2 pale setae near posterior margin. Anepimeron bare. Scutellum from brownish to black, with a pair of lateral scutellar and a pair of apical scutellar setae.

Legs. All femora black completely or brownish in ground color, all tibiae from yellow comletely to darkened, tarsi of all legs usually yellow. All setae of legs pale. Fore femur with 2-4 pale posterodorsal setae. Fore tibia with 1 dorsal/anterodorsal seta, 1 posterodorsal and 1 posterior setae at middle, 1 preapical dorsal and 1 apical posterior setae. Mid femur with 1 preapical posterodorsal seta. Mid tibia with 0 1 anterodorsal, 1 preapical dorsal setae and a ring of apical setae. Hind femur with 1-4 anterodorsal setae in apical half and $0-1$ preapical anterior seta. Hind tibia with 1 anterodorsal, 1 preapical dorsal setae, also with 1 apical anteroventral and 1 apical anterodorsal setae.

Wing slightly brownish; veins brownish. Vein $\mathrm{R}_{1}$ setulose on apical half of dorsal surface. Calypters, margins of calypters, and halteres whitish or yellowish.

Abdomen black or dark brown, usually subshining in male and shining in female. Male sternite 4 rectangular, wider than long; sternite 5 transverse with wide trapezoid median lobes, covered with spinules (Fig. $20)$. Epandrium, cercal plate and surstyli as in Figs 60 62.

DISTRIBUTION. Russia: Irkutsk Oblast, Magadan Oblast, Krasnoyarsk Krai.

\section{Gimnomera speciosa (Ozerov, 1999)}

speciosa Ozerov, 1999b: 511 (Langechristia). Type-locality: $30 \mathrm{~km}$ SE Chuguyevka $\left(44.05^{\circ} \mathrm{N}, 134.12^{\circ} \mathrm{E}\right.$ ) (Russia, Primorsky Krai).

This species is known from the type-locality only [Ozerov, 1999b].

DESCRIPTION (translated from description by Ozerov, 1999b: 511). "Female. Ocellar triangle and upper half of postcranium black. Frontal vitta reddishyellow. Face, gena, lower half of postcranium, palpus and proboscis pale yellow. Scapus and pedicel yellow. Postpedicel blackish, but yellow basally. Arista yellow in basal half and black in apical half. Scutum black, but postpronotum, alar and postalar areas yellow. Anatergite, katatergite, mediotergite and scutellum black completely. Meron in posterior half, upper part of metepisternum and metepimeron, also upper posterior corner of anepisternum blackish. The rest pleural parts of thorax yellow. Legs yellow. Abdomen black. Tergites $(1+2)-6$ each with a pair of yellow spots. Tergite 7 and sternite 7 yellow, but blackish along posterior margin. Sternites 1-6 yellow. Wing slightly brownish; with dark brown veins. All setae yellow, excluding black orbital, outer vertical and postocular setae. Postpronotum with yellow hairs. All hairs on pleural sclerites and on abdomen yellow.

Frontal vitta matt. Postcranium delicate greyish dusted. Scutum shining, only notopleuron and area along anterior margin greyish dusted. Scutellum shining. Pleu- 

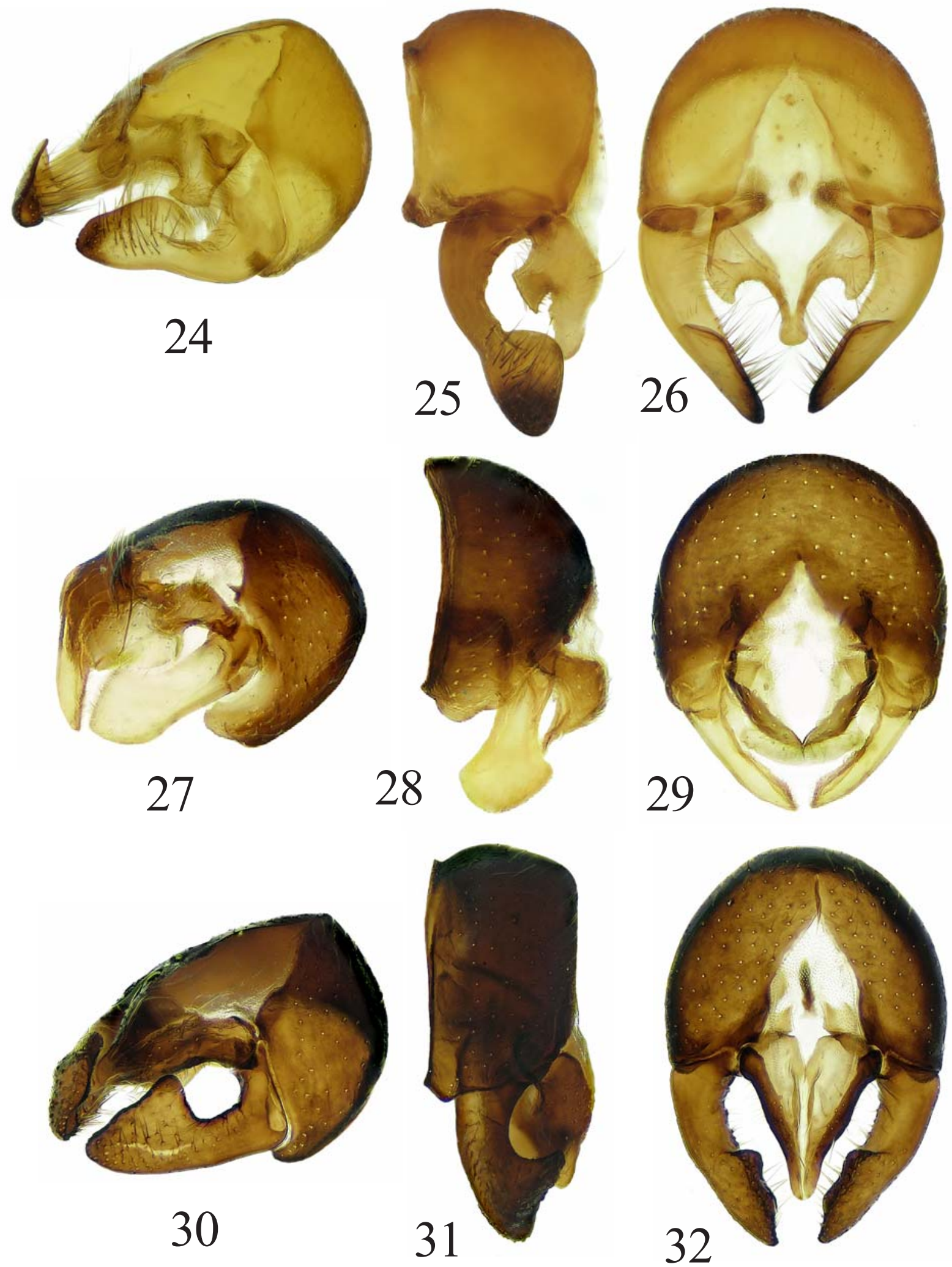

Figs 24-32. Epandrium, cercal plate and surstyli of Gimnomera spp.: 24-26 - G. alanica (Ozerov); 27-29 — G. albipila (Zetterstedt); $30-32$ - G. castanipes (Becker); 24, 27, 30 - dorsolateral view; 25, 28, 31 - lateral view; 26, 29, 32 - dorsal view.

Рис. 24-32. Эпандрий, щерки и сурстили Gimnomera spp. : 24-26 — G. alanica (Ozerov); 27-29 — G. albipila (Zetterstedt); 30-32 — G. castanipes (Becker); 24, 27, 30 - дорсолатерально; 25, 28, 31 - сбоку; 26, 29, 32 - сверху. 


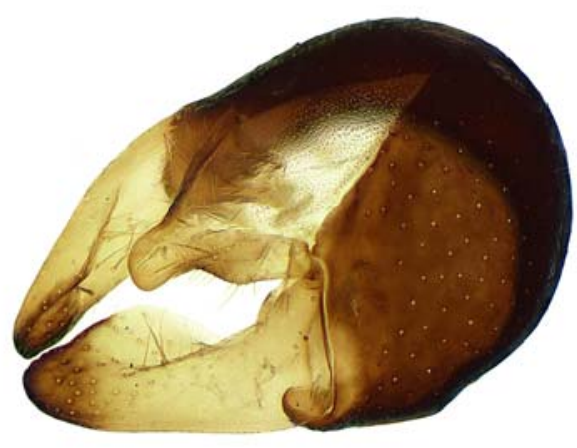

33
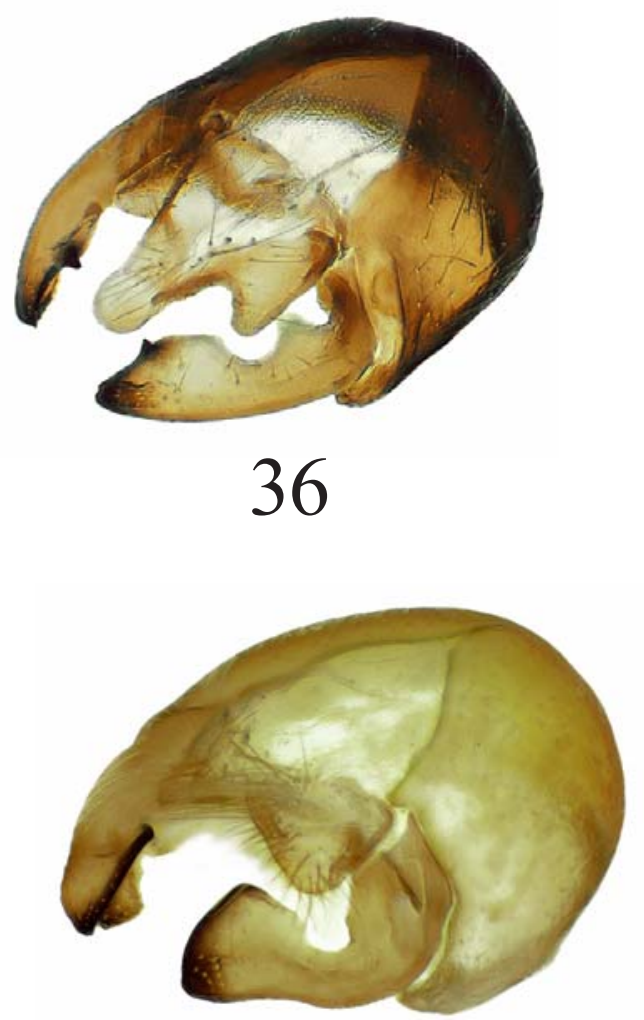

39
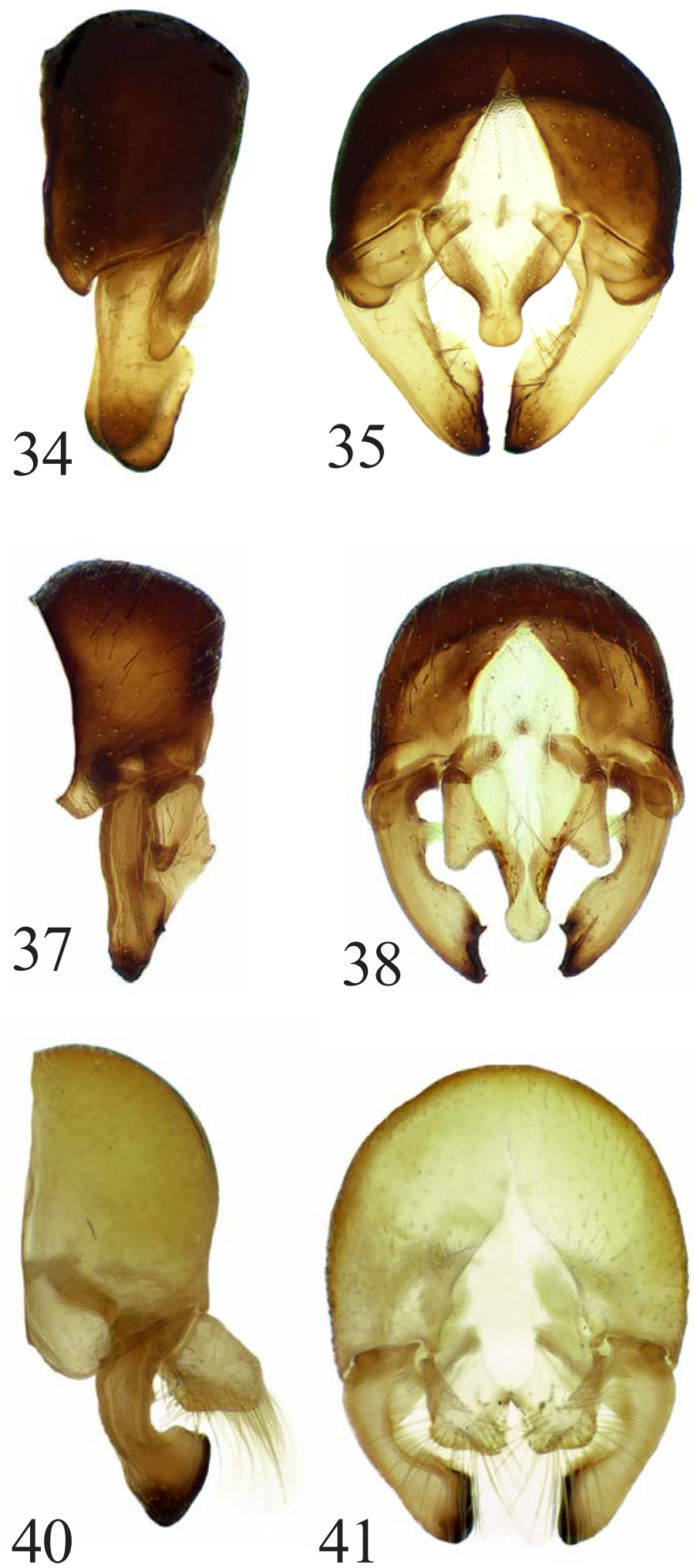

Figs 33-41. Epandrium, cercal plate and surstyli of Gimnomera spp.: 33-35 - G. cuneiventis (Zetterstedt); 36-38 - G. dorsata (Zetterstedt); 39-41 - G. hirta (Hendel); 33, 36, 39 - dorsolateral view; 34, 37, 40 - lateral view; 35, 38, 41- dorsal view.

Рис. 33-41. Эпандрий, церки и сурстили Gimnomera spp.: 33-35 - G. cuneiventis (Zetterstedt); 36-38 — G. dorsata (Zetterstedt); 39-41 - G. hirta (Hendel); 33, 36, 39 - дорсолатерально; 34, 37, 40 - сбоку; 35, 38, 41 - сверху. 

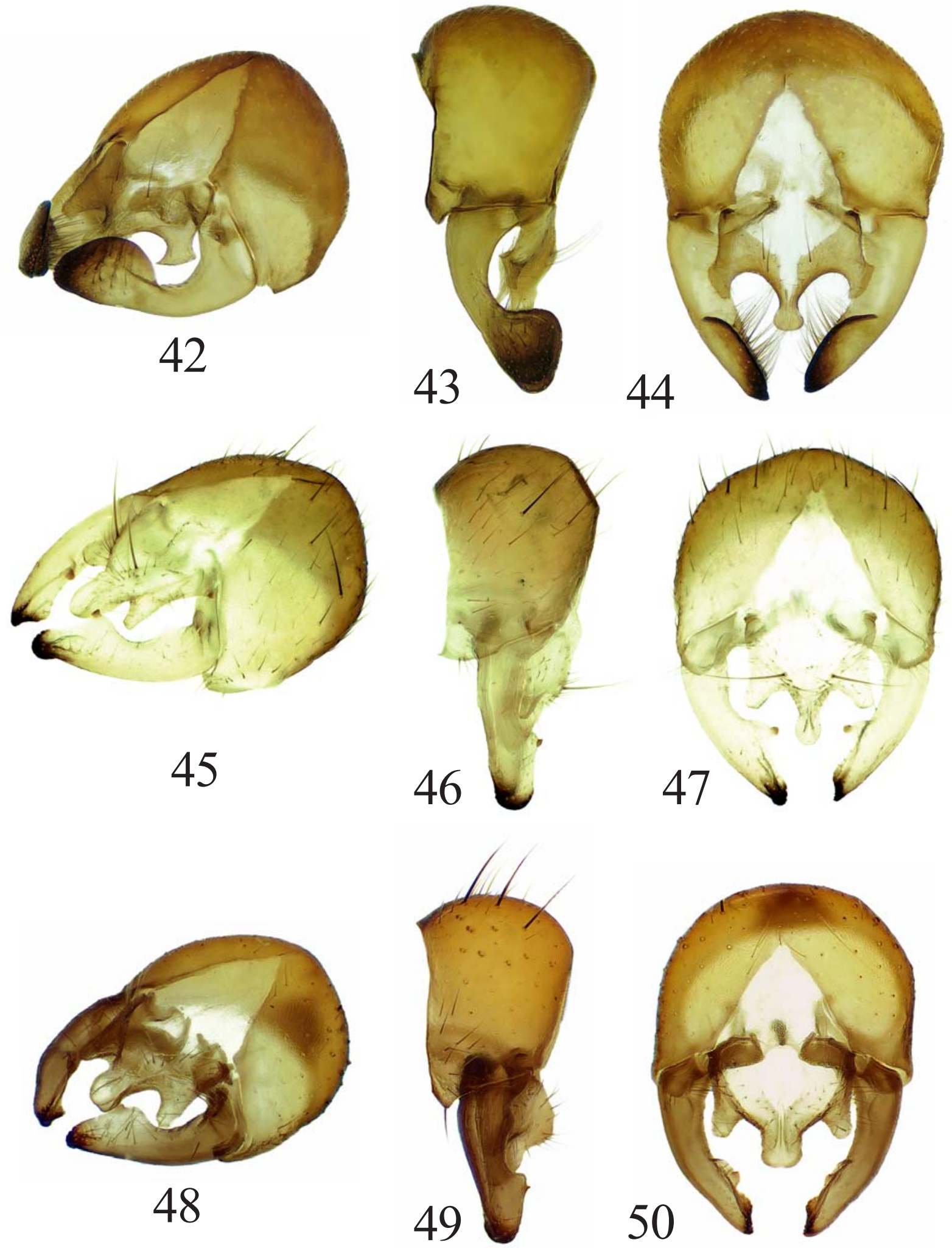

Figs 42-50. Epandrium, cercal plate and surstyli of Gimnomera spp.: 42-44 - G. lasiostoma (Becker); 45-47 - G. mellina (Becker); 48-50 - G. montana Ozerov et Krivosheina; 42, 45, 48 - epandrium, cerci and surstyli, dorsolateral view; 43, 46, 49 - same, lateral view; 44, 47, 50 - same, dorsal view.

Рис. 42-50. Эпандрий, церки и сурстили Gimnomera spp.: 42-44 - G. lasiostoma (Becker); 45-47 — G. mellina (Becker); 48-50 - G. montana Ozerov et Krivosheina; 42, 45, 48 - эпандрий, церки и сурстили, дорсолатерально; 43, 46, 49 — то же, сбоку; 44, 47, 50 - то же, сверху. 
ral sclerites delicate greyish dusted; mediotergite with shining spot near abdomen. Legs and abdomen shining.

Frons with 3 frontal and 3 orbital setae. Postpronotum with 2 setae."

Male unknown.

DISTRIBUTION. Russia: Primorsky Krai.

Gimnomera tarsea (Fallén, 1819)

Figs 1, 21, 63-65.

tarsea Fallén, 1819: 8 (Cordylura). Type-locality: "Uplandia... Scania..." (Sweden).

Noted by Gorodkov [1986] for the European part of Russia without indicating specific locality.

MATERIAL. Arkhangelsk Oblast: Nizhnyaya Pesha $\left(66.7518^{\circ} \mathrm{N}\right.$ 47.7605 $\left.{ }^{\circ} \mathrm{E}\right), 22$. VIII.1978, Gorodkov (1 +, ZISP); Belush'e env. $\left(66.89^{\circ} \mathrm{N} 47.61^{\circ} \mathrm{E}\right), 24$. VIII.1978, Gorodkov (1 $\circ$, ZISP); Karelia: Primorskiy $\left(66.5463^{\circ} \mathrm{N} 33.1036^{\circ} \mathrm{E}\right), 3-6 . V I I .2010$, A.L. Ozerov (3 $\sigma^{7} \sigma^{7}, 24$ O⿱㇒ , ZMUM); Komi: Shchel'yabozh $\left(66.29^{\circ} \mathrm{N} 56.45^{\circ} \mathrm{E}\right)$ 14.VIII.1978, Gorodkov (4 $\sigma^{7} \sigma^{7}$, ZISP); Leningrad Oblast: Shuvalovo $\left(60.0478^{\circ} \mathrm{N} 30.2833^{\circ} \mathrm{E}\right)$, 9.V.1897, Yakobson (1 $\sigma^{7}$, ZISP); Fan-der-Flit station $\left(58.6415^{\circ} \mathrm{N} 29.6935^{\circ} \mathrm{E}\right), 13-27 . V I .1925$, A. Sta-

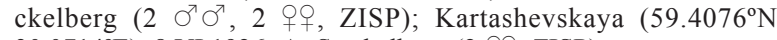
30.0714 ${ }^{\circ}$ E), 8.VI.1926, A. Stackelberg (2 90 , ZISP).

DESCRIPTION. Male, female. Medium-sized flies (4.1-5.8 mm long).

Yellow or reddish-yellow species, only ocellar triangle and postpedicel black, also female abdominal tergites narrowly black along posterior margin. Scutum shining, the rest parts of thorax whitish microtrichose. Abdomen subshining in male and shining in female.

Head with 2-3 orbital, 3 frontal, 1 ocellar, 1 small postocellar, 1 inner vertical, 1 outer vertical setae; 1 pair of vibrissae present. Postpedicel approximately 2.0 times as long as wide. Arista black. Palpus yellow.

Thorax. Acrostichals as hairs in two rows, dorsocentrals $2+(1-2)$, intra-alars $(0-1)+0$, supra-alars $1+2$, 1 postpronotal, anterior margin of postpronotum with short erect black spinules, notopleurals 2, postalars 2 . Proepisternum with 1 seta near lower margin. Proepimeron with 1 seta and several hairs. Anepisternum with 1-2 setae near posterior margin. Anepimeron bare. Scutellum black, with a pair of lateral scutellar and a pair of apical scutellar setae.

Legs. Fore femur with 2-4 posterodorsal setae in apical half. Fore tibia with 1-2 anterodorsal, 1 posterodorsal and 1-2 posterior setae at middle, also with 1 preapical dorsal, 1 apical anterodorsal and 1 apical posterior setae. Mid femur with 4-7 anterior setae in apical half, 0-1 preapical posterodorsal and 1 preapical posterior setae. Mid tibia with 1 anterodorsal, 0-1 posterodorsal, 1 preapical dorsal setae and a ring of apical setae. Hind femur with 2-5 anterodorsal setae in apical half, also with $0-1$ preapical posterodorsal and 0-1 preapical posterior setae. Hind tibia with 2 anterodorsal, 1 posterodorsal, 1 preapical dorsal setae, also with 1 apical anteroventral and 1 apical anterodorsal setae.

Wing slightly brownish; veins brownish. Vein $\mathrm{R}_{1}$ setulose on apical half of dorsal surface. Calypters, margins of calypters, and halteres yellowish.
Abdomen. Male sternite 4 oval, wider than long; sternite 5 transverse, with moderate median lobes, carrying spinules (Fig. 21). Epandrium, cercal plate and surstyli as in Figs 63-65.

DISTRIBUTION. Russia: Arkhangelsk Oblast, Karelia, Komi, Leningrad Oblast. — Europe [Šifner, 2008].

Gimnomera tibialis (Malloch, 1919)

Figs 22, 66-68.

tibialis Malloch, 1919: 79 (Dasypleuron). Type-locality: Collinson point, Alaska (USA).

sibiricum Engelmark, 1999: 164 (Cochliarium). Type-locality: Wrangel Island $\left(70^{\circ} 58^{\prime} \mathrm{N}, 179^{\circ} 34^{\prime} \mathrm{E}\right)$ (Russia) - syn.n.

The species was recorded for Russia as Cochliarium sibiricum Engelmark, 1999 from Wrangel Island [Engelmark, 1999].

MATERIAL. Chukotka: Meynypil'gyno env. $\left(62.567^{\circ} \mathrm{N}\right.$ 177.033 ${ }^{\circ}$ E), 23-27.VI.2011, P.C. Tomkovich (1 $\sigma^{7}$, ZMUM); Vrangel Is., Somnitel'naya bay (ca. $\left.70.9431^{\circ} \mathrm{N} 179.6141^{\circ} \mathrm{W}\right), 3,9$ and

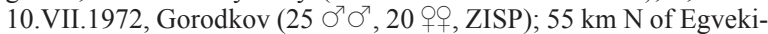
not $\left(66.7956^{\circ} \mathrm{N} 181.00052^{\circ} \mathrm{E}\right), 29$. VII.1963, Gorodkov $\left(2 \sigma^{7} \sigma^{7}\right.$, ZISP); Shmidt (ca. $\left.68.8703^{\circ} \mathrm{N} 179.3744^{\circ} \mathrm{W}\right), 11$ and 18.VII.1963, Gorodkov (3 $\sigma^{7} \sigma^{7}$, ZISP); $\mathrm{S}$ of Vrangel Is. (ca. $71.0294^{\circ} \mathrm{N}$

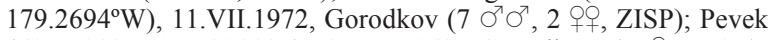
$\left(69.7022^{\circ} \mathrm{N} 170.2982^{\circ} \mathrm{E}\right)$, 3.VII.1963, Gorodkov (1 O, ZISP); Komsomol'skiy $\left(69.1309^{\circ} \mathrm{N} 172.7358^{\circ} \mathrm{E}\right)$, 7.VII.1963, Gorodkov ( $1 \mathrm{O}^{7}$, ZISP); Krasnoyarsk Krai: Agapa (ca. $71.412^{\circ} \mathrm{N} 89.2689^{\circ} \mathrm{E}$ ), the River Pyasina, 15.VII.1967, Gorodkov (1 9 , ZISP).

ADDITIONAL MATERIAL. Holotype of Cochliarium sibiricum Engelmark, 1999 ( $\sigma^{\top}$, "Russia: Wrangel Island $\left(70^{\circ} 58^{\prime} \mathrm{N}\right.$, 179³4'E), site 17, 23-24.VII.1994, leg. S.A. Bengtson" (MZLU); is conspecific with Gimnomera tibialis); Canada: "Victoria Is., N.W.T., $71^{\circ} 17^{\prime} \mathrm{N}, 114^{\circ} \mathrm{W}, 23-28$.VII.1975, G. \& M. Wood (1 $\sigma^{\top}, 1$ q, ZMUM); Herschel Is., Y.T., 11.VII.1953, J.S. Waterhouse (1 O', 1 i , ZMUM).

DESCRIPTION. Male, female. Small or mediumsized flies (3.1-4.6 mm long).

Head. Frontal vitta usually reddish-yellow, sometimes black in upper half and yellow in lower part, matt; fronto-orbital plate black, whitish dusted. Ocellar triangle black. Face blackish, whitish dusted. Parafacial and gena yellow, whitish dusted. Postcranium black, greyish dusted. 2-3 orbitals, 2-3 frontals, 1 ocellar, 1 small postocellar, 1 inner vertical, 1 outer vertical; 1 pair of vibrissae present. Antenna black. Postpedicel approximately 1.5 times as long as wide. Arista black. Palpus brownish.

Thorax black, greyish dusted, only scutum with two shining wide interrupted stripes between dorsocentral and supra-alar setae. Acrostichals as hairs in two rows, dorsocentrals $2+(2-3)$, intra-alars $(0-1)+(0-1)$, supraalars $1+2$, postpronotals $1-2$ (usually 2 ), anterior margin of postpronotum with short erect black spinules, notopleurals 2, postalars 2. Proepisternum with 1 seta near lower margin. Proepimeron with 1 seta and several hairs. Anepisternum with 1-2 setae near posterior margin. Anepimeron with several hairs. Scutellum black, with a pair of lateral scutellar and a pair of apical scutellar setae.

Legs black in ground colour, but usually fore tibia and sometimes mid and hind tibiae yellowish. Fore femur with a row of posterodorsal setae. Fore tibia with 
0-1 dorsal/anterodorsal seta, 1 posterior and 1 preapical dorsal setae. Mid femur with $0-1$ anterior seta at middle, $0-1$ preapical posterodorsal and 1 preapical posterior setae. Mid tibia with $0-1$ anterodorsal, 1 preapical dorsal setae and a ring of apical setae. Hind femur with a row of anterodorsal and a row of anteroventral setae and $0-1$ preapical posterodorsal seta. Hind tibia with 1-2 anterodorsal, $0-1$ posterodorsal, 1 preapical dorsal setae, also with 1 apical anteroventral seta.

Wing slightly brownish; veins brownish. Vein $\mathrm{R}_{1}$ setulose on apical half of dorsal surface. Calypters, margins of calypters, and halteres greyish.

Abdomen black, subshining in male and shining in female. Male sternite 4 rectangular, about 3 times as wide as long, covered with long setae; sternite 5 narrow, with conical median lobes, covered with spinules and long setae (Fig. 22). Epandrium, cercal plate and surstyli as in Figs 66-68.

DISTRIBUTION. Russia: Chukotka, Krasnoyarsk Krai. - Nearctic [Vockeroth, 1965].

\section{Gimnomera tukuringra (Ozerov, 1999)}

tukuringra Ozerov, 1999a: 636 (Cochliarium). Type-locality: town Zeya (Russia).

This species was described from Amur Oblast [Ozerov, 1999a] and is known only from the type-locality.

MATERIAL. Holotype of Cochliarium tukuringra Ozerov [Ozerov, 1999a: 636].

DESCRIPTION. Female. Medium-sized flies (3.4 mm long).

Head. Frontal vitta yellow, matt; fronto-orbital plate yellow, shining in upper half and whitish dusted in lower part. Ocellar triangle black. Face, parafacial and gena yellow, parafacial shining, face and gena whitish dusted. Postcranium black in upper third and yellow in lower part, shining (median occipital sclerite subshining). $2-3$ orbitals, 2 frontals, 1 ocellar, 1 small postocellar, 1 inner vertical, 1 outer vertical; 2 pairs of vibrissae present. Antenna black, but scapus and pedicel lighter than postpedicel. Postpedicel approximately 1.5 times as long as wide. Arista black. Palpus yellow.

Thorax yellow in ground colour and mostly subshining. Scutum with two washed blackish stripes along dorsocental lines, densely covered with small yellow hairs, including acrostichal area. Dorsocentrals $0+1$, intra-alars absent, supra-alars $0+1$, postpronotal absent, notopleurals 2, anterior margin of postpronotum with short erect black spinules, postalars 2 . Proepisternum with 1 seta near lower margin. Proepimeron with 1 seta and several hairs. Anepisternum shining, with 1 long seta near posterior margin. Anepimeron with several hairs. Scutellum yellow, subshining, with a pair of lateral scutellar and a pair of apical scutellar setae.

Legs yellow, only tarsomeres $3-5$ of all legs darkened. Fore femur with 3-4 posterodorsal setae. Fore tibia with 1 dorsal/anterodorsal seta and 1 preapical dorsal setae. Mid femur with 1 preapical posterodorsal seta. Mid tibia with 1 anterodorsal, 1 preapical dorsal setae and a ring of apical setae. Hind femur with 2-3 anterodorsal setae in apical half. Hind tibia with 1-2 anterodorsal, 1 preapical dorsal setae, also with 1 apical anteroventral seta.

Wing slightly yellowish; veins brownish. Vein $\mathrm{R}_{1}$ setulose on apical third of dorsal surface. Calypters, margins of calypters, and halteres whitish.

Abdomen yellowish, shining, darkened medially, also tergites narrowly black along posterior margin.

Male unknown.

DISTRIBUTION. Russia: Amur Oblast.

\section{Gimnomera ziegleri (Ozerov, 1999)}

Figs 23, 69-71.

ziegleri Ozerov, 1999b: 510 (Langechristia). Type-locality: Boitsovo $47.02^{\circ} \mathrm{N} 134.21^{\circ} \mathrm{E}$ (Russia, Khabarovsk Krai).

This species was known from the type-locality only [Ozerov, 1999b].

MATERIAL. Khabarovsk Krai: Malyshevo $\left(48.7324^{\circ} \mathrm{N}\right.$ 135.613 $1^{\circ} \mathrm{E}$ ), 13.V.1973, Gorodkov (2 $\sigma^{7} \sigma^{7}$, ZISP); Bychikha $\left(48.2978^{\circ} \mathrm{N} 134.8316^{\circ} \mathrm{E}\right), 16 . V .1973$, Gorodkov (2 90 , ZISP).

DESCRIPTION. Male, female. Medium-sized flies (3.7-4.8 mm long).

Head. Frontal vitta reddish-yellow, matt; frontoorbital plate black in upper half and yellow in lower part, whitish dusted. Ocellar triangle black. Gena and parafacial yellow, whitish dusted. Face blackish, whitish dusted. Postcranium black, greyish dusted. 2-3 orbitals, 3-4 frontals, 1 ocellar, 1 small postocellar, 1 inner vertical, 1 outer vertical; 2 pairs of vibrissae present. Antenna yellow, only postpedicel darkened apically. Postpedicel approximately 1.5 times as long as wide. Arista brownish. Palpus yellow.

Thorax black, greyish dusted, but postpronotum shining, also scutum with fore shining stripes (two linear along dorsocental setae and two wide between dorsocentral and supra-alar setae), sometimes additionally with short shining stripe along acrostichal lines in presutural area. Acrostichals as hairs in two rows, dorsocentrals $2+3$, intra-alars $0+1$, supra-alars $1+2,1$ postpronotal, anterior margin of postpronotum without short erect black spinules (Fig. 3), notopleurals 2, postalars 2. Proepisternum with 1 seta near lower margin. Proepimeron with 1 seta and several hairs. Anepisternum with 1 long black seta near posterior margin. Anepimeron bare. Scutellum black, shining, with a pair of lateral scutellar and a pair of apical scutellar setae.

Legs yellow completely. Fore femur with 1-3 posterodorsal setae. Fore tibia with 1 dorsal/anterodorsal seta, and 1 posterior setae at middle, 1 preapical dorsal, 1 apical posterior and 1 apical ventral setae. Mid and hind femora without striking setae. Mid tibia with 1 anterodorsal, 1 posterodorsal, 1 preapical dorsal setae and a ring of apical setae. Hind tibia with 1-2 anterodorsal, 2-3 posterodorsal, 1 preapical dorsal setae, also with 1 apical anterodorsal and 1 apical anteroventral setae.

Wing slightly brownish; veins brownish. Vein $\mathrm{R}_{1}$ setulose on apical half of dorsal surface. Calypters, margins of calypters, and halteres pale yellow. 


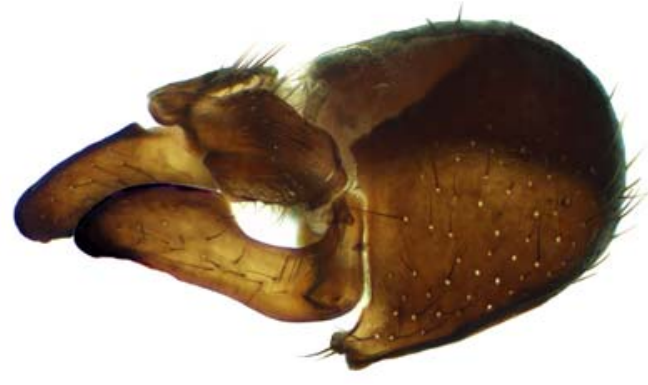

51

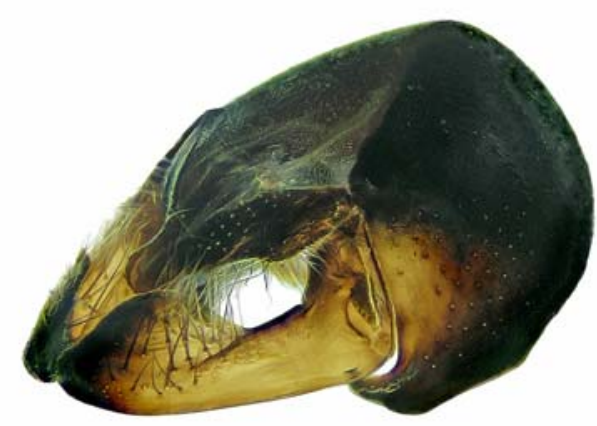

54

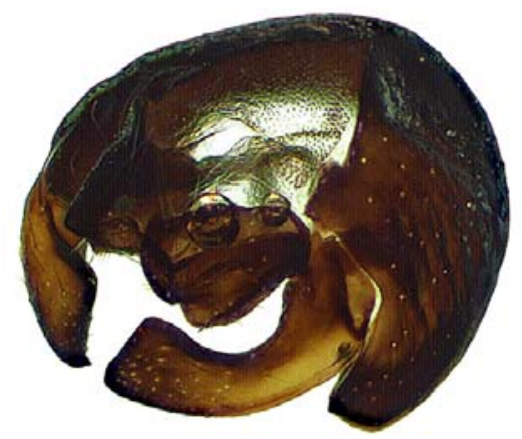

57
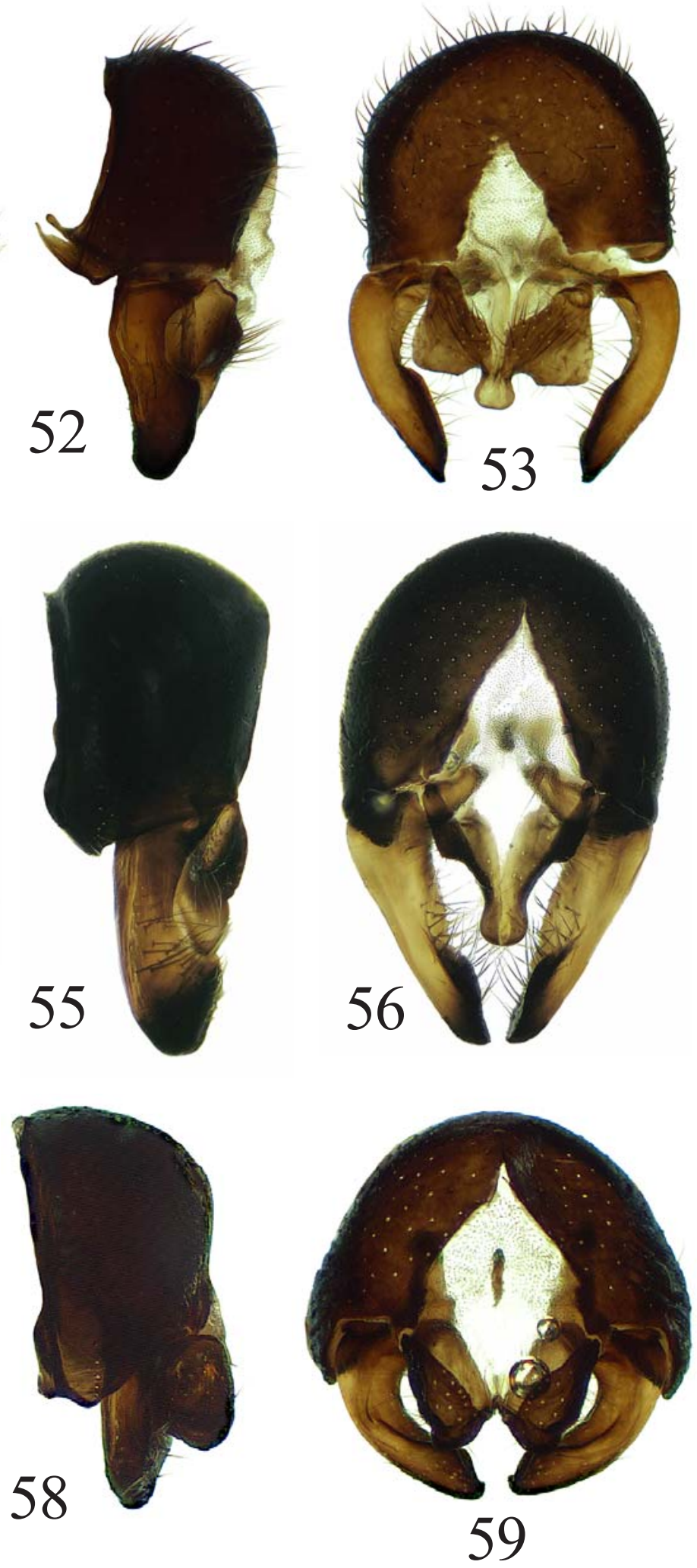

Figs 51-59. Epandrium, cercal plate and surstyli of Gimnomera spp.: 51-53 - G. nigricorpus sp.n.; 54-56 - G. novgorodovae (Ozerov); 57-59-G. nudipedis sp.n.; 51, 54, 57 - dorsolateral view; 52, 55, 58 - lateral view; 53, 56, 59 - dorsal view.

Рис. 51-59. Эпандрий, церки и сурстили Gimnomera spp.: 51-53 - G. nigricorpus sp.n.; 54-56 - G. novgorodovae (Ozerov); 57-59- G. nudipedis sp.n.; 51, 54, 57 — дорсолатерально; 52, 55, 58 - сбоку; 53, 56, 59 — сверху. 

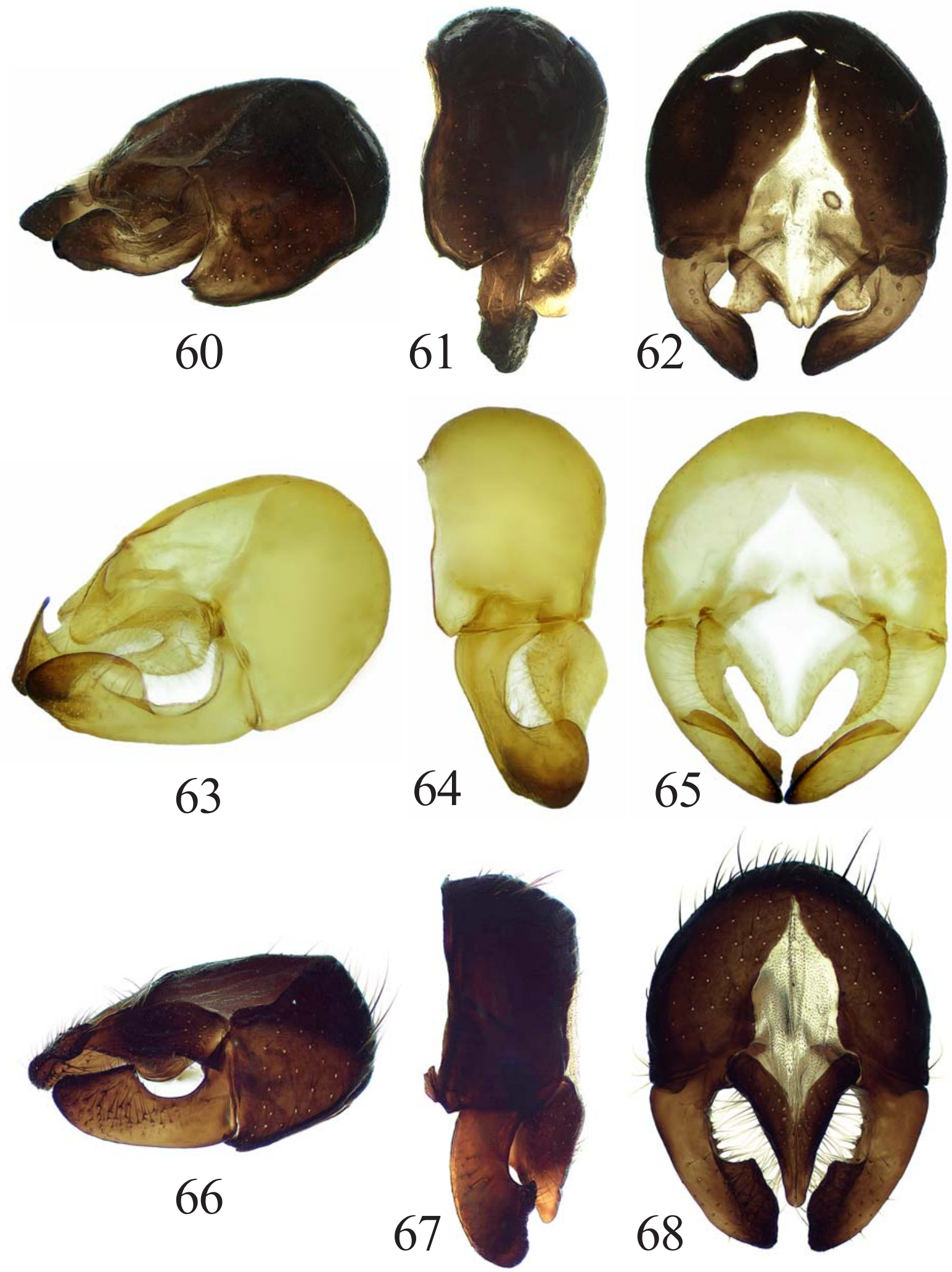

Figs 60-68. Epandrium, cercal plate and surstyli of Gimnomera spp.: 60-62 - G. palliseta sp.n.; 63-65 - G. tarsea (Fallén); 66-68 - G. tibialis (Malloch); 60, 63, 66 - dorsolateral view; 61, 64, 67 - lateral view; 62, 65, 68 - dorsal view.

Рис. 60-68. Эпандрий, церки и сурстили Gimnomera spp.: 60-62 - G. palliseta sp.n.; 63-65 — G. tarsea (Fallén); 66-68 - G. tibialis (Malloch); 60, 63, 66 - дорсолатерально; 61, 64, 67 - сбоку; 62, 65, 68 - сверху. 

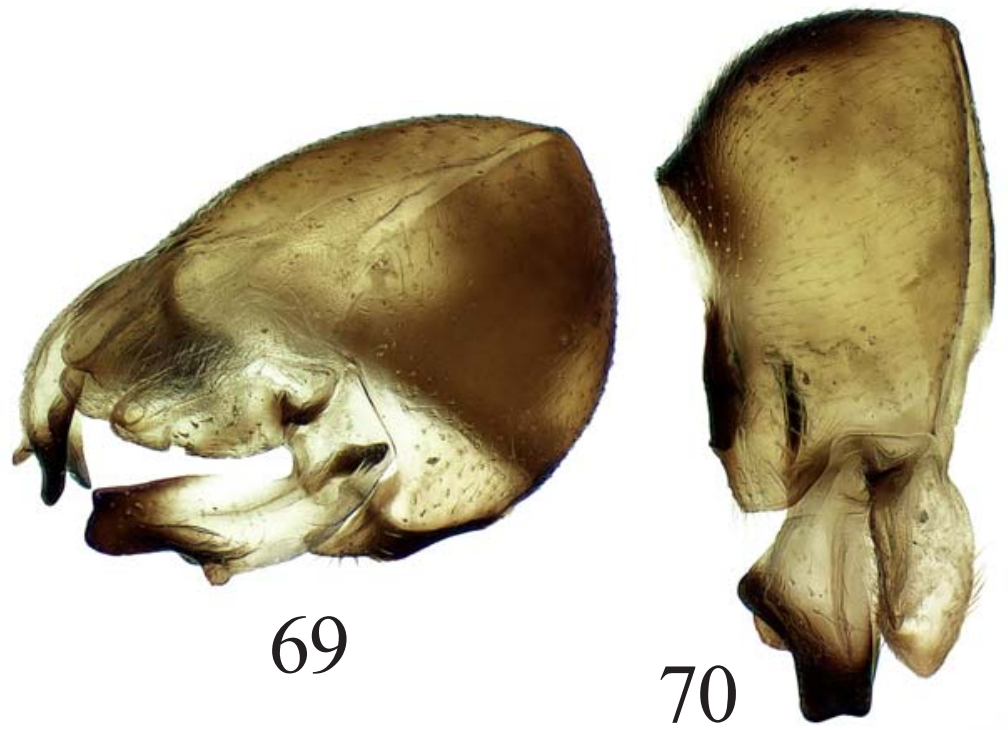

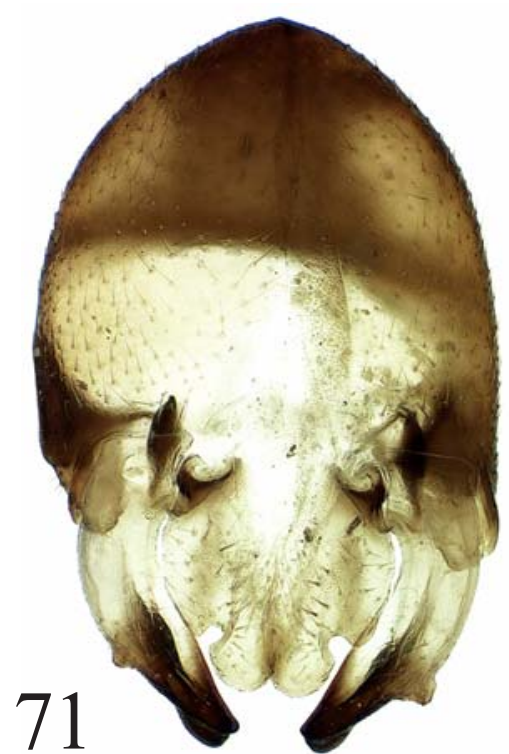

Figs 69-71. Epandrium, cercal plate and surstyli of G. ziegleri (Ozerov): 69 — dorsolateral view; 70 — lateral view; 71 - dorsal view.

Рис. 69-71. Эпандрий, церки и сурстили G. ziegleri (Ozerov): 69 — дорсолатерально; 70 — сбоку; 71 — сверху.

Abdomen black in ground colour. Male syntergite $1+2$ with two yellow lateral spots (visible dorsally); tergites 3-6 each black, but yellow near lateral margin (not visible dorsally); tergite 7 and epandrium yellow. Female syntergite $1+2$ and tergites $3-4$ each with large yellow lateral spots; tergites 5-6 each yellow, with narrow medial stripe; tergite 7 yellow completely. Male sternite 4 small, circular; sternite 5 transverse, with moderate hummock shaped median lobes, carrying spinules (Fig. 23). Epandrium, cercal plate and surstyli as in Figs 69-71.

DISTRIBUTION. Russia: Khabarovsk Krai.

\section{Key to THE SPECIES OF GIMNOMERA OF RUSSIA}

1. Anterior margin of postpronotum with short erect black spinules (Fig. 2)

- Anterior margin of postpronotum without erect spinules (Fig. 3)

2. Scutellum with a pair of apical scutellar setae only, basal scutellar or lateral scutellar setae absent

- Scutellum with two pairs of strong setae: a pair of basal or lateral scutellar and a pair of apical scutellar setae .... 6

3. Postpronotal lobe with strong seta ................................. 4

- Postpronotal lobe without strong seta .......................... 5

4. Dorsocentral presutural setae absent. Male sternite 4 and 5, epandrium, cercal plate and surstyli as in Figs 8, 24 26.

G. alanica (Ozerov)

- Two pairs of dorsocentral presutural setae present (anterior pair sometimes small). Male sternite 4 and 5, epandrium, cercal plate and surstyli as in Figs 17, 51-53 ....

G. nigricorpus sp.n.

5. Vein $\mathrm{R}_{1}$ bare on apical half of dorsal surface. Anepimeron bare. Male sternite 4 and 5, epandrium, cercal plate and surstyli as in Figs 15, 45-47 ........... G. mellina Becker

- Vein $R_{1}$ with several setulae on apical half of dorsal surface. Anepimeron with several hairs. Male sternite 4 and 5, epandrium, cercal plate and surstyli as in Figs 14, 42-44 ....................................... G. lasiostoma Becker

6. Vein $\mathrm{R}_{1}$ bare dorsally on apical half ...

- Vein $\mathrm{R}_{1}$ with several setulae dorsally on apical Fig. 4)

7. Anepimeron bare. Fore tibia with 1-2 dorsal posterodorsal and 1 posterior setae except apicals. Mid tibia with 1 posterodorsal, 1 posterior, 1 anterodorsal except apicals ....

- Anepimeron with several hairs. Fore and mid tibiae without setae except apicals. Male sternite 4 and 5, epandrium, cercal plate and surstyli as in Figs 19, 57-59....

G. nudipedis sp.n.

8. Fore femur with $2-3$ posterodorsal setae in apical quarter or third. Male sternite 4 ovoid, about as long wide (Fig. 12). Cercal plate longer than wide (Fig. 38) ...

G. dorsata (Zetterstedt)

- Fore femur with 4-6 posterodorsal setae passing the middle of femur. Male sternite 4 rectangular, about 1.5 times long as wide (Fig. 16). Cercal plate as wide as long (Fig. 50) ............... G. montana Ozerov et Krivosheina

9. Anepimeron with several hairs .................................... 10

- Anepimeron bare ...................................................... 16

10. Postpedicel yellow. Male sternite 4 and 5 , epandrium, cercal plate and surstyli as in Figs 13, 39-41...

$$
\text { G. hirta (Hendel) }
$$

— Postpedicel black ........................................................ 11

11. Postpronotal lobe without strong setae ....................... 12

- Postpronotal lobe with 1-2 strong setae .................... 15

12. Acrostichals as hairs in two rows. Male sternite 4 and 5 , epandrium, cercal plate and surstyli as in Figs 10, 30-32 G. castanipes (Becker)

- Scutum densely covered with numerous small yellow hairs, including acrostichal area, acrostichals not form rows ......

13

13. Notopleuron with one seta. Fore coxa black. Male sternite 4 and 5, epandrium, cercal plate and surstyli as in Figs 18, 54-56 ................. G. novgorodovae (Ozerov) - Notopleuron with 2 setae. Fore coxa yellow ............... 14 
14. Thorax yellow G. tukuringra (Ozerov) (female, male unknown)

- Thorax black. Male sternite 4 and 5, epandrium, cercal plate and surstyli as in Figs 11, 33-35.....

G. cuneiventris (Zetterstedt)

15. Scutum with $0-1$ pairs of presutural dorsocentral setae and one pair of postsutural dorsocentral setae. Postpronotal lobe with one seta, offen small. Male sternite 4 and 5, epandrium, cercal plate and surstyli as in Figs 10, $30-32$.. G. castanipes (Becker)

- Scutum with two pairs of presutural dorsocentral setae and 2-3 pairs of postsutural dorsocentral setae. Postpronotal lobe ussually with 2 strong setae. Male sternite 4 and 5, epandrium, cercal plate and surstyli as in Figs $22,66-68$ G. tibialis (Malloch)

16. Postpronotal lobe without strong setae. Male sternite 4 and 5, epandrium, cercal plate and surstyli as in Figs 20, 60-62 ............................................. G. palliseta sp.n

- Postpronotal lobe with 1-2 strong setae .................... 17

17. Postpedicel yellow. Male sternite 4 and 5, epandrium, cercal plate and surstyli as in Figs 16, 48-50

G. montana Ozerov et Krivosheina

- Postpedicel black. Male sternite 4 and 5, epandrium, cercal plate and surstyli as in Figs 21, 63-65

G. tarsea (Fallén)

18. Abdomen black

19

— Abdomen with yellow spots .......................................... 20

19. Scapus and pedicel yellow. Anepisternum, katepisternum and anepimeron mostly shining

G. amica (Ozerov)

(female, male unknown)

- Scapus and pedicel black. Lateral pleural sclerites of thorax greyish dusted (microtrichose). Male sternite 4 and 5, epandrium, cercal plate and surstyli as in Figs 9 , $27-29$.

G. albipila (Zetterstedt)

20. Lateral pleural sclerites of thorax black completely. All setae on scutum and scutellum black. Male sternite 4 and 5, epandrium, cercal plate and surstyli as in Figs 23, 6971. G. ziegleri (Ozerov)

- Lateral pleural sclerites of thorax yellow, only anepimeron, meron and katetergite blackish. All setae on scutum and scutellum yellow G. speciosa (Ozerov) (female, male unknown)

Acknowledgements. This study was supported by research project of Moscow State University Zoological Museum (AAAA-A16-116021660077-3, depository of specimens, collecting of specimens and morphological study).

We are very grateful to Dr. Olga Ovchinnikova (ZISP) and Mrs. Galina Suleymanova (ZISP) for the loan of the material of Gimnomera for study.

\section{References}

Becker T. 1894. Dipterologische Studien. I. Scatomyzidae // Berliner Entomologische Zeitschrift. Bd.39. Heft 1. S.77-196.

Becker Th. 1900. Beiträge zur Dipteren-Fauna Sibiriens. Nordwest-Sibirische Dipteren gesammelt vom Prof. John Sahlberg aus Helsingfors im Jahre 1876 und vom Dr. E. Bergroth aus Tammerfors im Jahre 1877 // Acta Societatis Scientiarum Fennicae. T.26. No.9. S.1-66.

Chandler P.J. 1975. The early stages of Gimnomera tarsea Fallén (Diptera, Scatophagidae) now established to develop in the seed capsules of Pedicularis species (Scrophulariaceae). // Proceedings of the British Entomological and Natural History Society. Vol.8. P.39-41.

Cumming J.M., Wood D.M. 2009. Adult morphology and terminology // Brown B.V., Borkent A., Cumming J.M., Wood D.M., Woodley N.E., Zumbado M. (eds.). Manual of Central American Diptera. Vol.1. Ottawa: National Research Council Press. P.9-50.

Enderlein G. 1936. Zweiflügler // Bromer P., Ehrman P., Ulmer G. (Hrsg.). Die Tierwelt Mitteleuropas. Insecten. Teil 3. Leipzig: Quelle \& Meyer. 259 S.

Engelmark R. 1999. Dungflies (Diptera: Scathophagidae) collected by the Swedish-Russian tundra ecology expedition '94, with the description of two new species; Nanna indotatum and Cochliarium sibiricum // Entomologisk Tidskrift. Arg.120. Häft 4. P.157-167.

Fallén C.F. 1819. Scatomyzides. Lundae. 10 pp.

Gorodkov K.B. 1970. Family Scathophagidae (Cordyluridae, Scatomyzidae, Scopeumatidae). P. 440-458. // Bei-Bienko G.Y. (Ed.). Key to the insects of the European part of the USSR. Vol. V. Diptera, Siphonaptera. Part 2. 943 pp. [in Russian].

Gorodkov K.B. 1986. Family Scathophagidae. P.11-41. Soós Á, Papp L. (eds): Catalogue of Palaearctic Diptera. Vol.11. Scathophagidae-Hypodermatidae. Akadémiai Kiadó, Budapest. 346 $\mathrm{pp}$

Hendel F. 1930. Eine neue Gymnomera-Art (Dipt., Cordyluridae) aus Schweden // Konowia. Bd.9. S.79-80.

Khaghaninia S., Gharajedaghi Y. 2014. Dung flies fauna (Diptera: Scathophagidae) in East Azerbaijan province of Iran, with eight new records // Journal of Crop Protection. Vol.3. No.3. P. 389-396.

Malloch J.R. 1919. The Diptera collected by the Canadian Expedition, 1913-1918. (Excluding the Tipulidae and Culicidae.) // Anderson R.M. (ed.). Report of the Canadian Arctic Expedition 1913-18. Vol.3: Insects. Part C: Diptera. Ottawa. P.3490.

McAlpine J.F. 1981. Morphology and terminology-adults // McAlpine J.F., Peterson B.V., Shewell G.E, Teskey H.J., Vockeroth J.R., Wood D.M. (Coordinators). Manual of Nearctic Diptera. Vol.2. Ottawa: Research Branch. Agriculture Canada. Monograph 27. P.9-63.

Neff S.N. 1968. Observation on the immature stages of Gimnomera cerea and G. insurata (Diptera: Anthomyiidae, Scatophaginae). // Canadian Entomologist. Vol.100. No.1. P.74-83.

Ozerov A.L. 1999a. [To the fauna of Cochliarium (Diptera, Scathophagidae)] // Zoologicheskiy zhurnal. Vol.78. No.5. P.635637 [in Russian].

Ozerov A.L. 1999b. [New genus and three new species of Scathophagidae (Diptera) from the Russian Far East] // Zoologicheskiy zhurnal. Vol.78. No.4. P.510-512 [in Russian].

Ozerov A.L. 2006. New species of the family Scathophagidae from Altai and Far East of Russia // Euroasian Entomological Journal. Vol.5. No.4. P.333-336 [in Russian].

Ozerov A.L. 2009. New species of Scathophagidae (Diptera) // Russian Entomological Journal. Vol.17. No.4(2008). P.419-427.

Ozerov A.L., Barkalov A.V. 2014. On the fauna of Scathophagidae (Diptera) of Taimyr Peninsular (Russia: Krasnoyarskiy Kray) // Euroasian Entomological Jornal. Vol.13. No.6. P.560-565.

Ozerov A.L., Krivosheina M.G. 2013. New and little known palaearctic species of Scathophagidae (Diptera) // Far Eastern Entomologist. N.270. P.1-6.

Ozerov A.L., Krivosheina M.G. 2014. To the fauna of dung flies (Diptera: Scathophagidae ) of Russian Far East // Russian Entomological Journal. Vol.23. No.3. P.203-222.

Rondani C. 1866. Scatophaginae Italicae collectae distinctae et in ordinem dispositae. Dipterolodiae Italicae Prodromus. Pars.VII. Fasc.I. Bernardoni, Milano. 52 pp.

Ryden N. 1933. Gynmomera hirta Hend., ein neuer Bluten Minierer. // Entomologisk Tidskrift. Vol.54. P.49.

Šifner F. 2008. A catalogue of the Scathophagidae (Diptera) of the Palaearctic region, with notes on their taxonomy and faunistics // Acta Entomologica Musei Nationalis Pragae. Vol.48. No.1. P.111-196. 
Strobl G. 1894. Die Dipteren von Steiermark. II. Theil. // Mitteilungen des Naturwissenschaftlichen Vereines für Steiermark, Vol.30. S.1-152.

Stuckenberg B.R. 1999. Antennal evolution in the Brachycera (Diptera), with a reassessment of terminology relating to the flagellum // Studia Dipterologica. Vol.6. S.33-48.

Vockeroth J.R. 1965. Subfamily Scatophaginae. P.826-842. Stone A. et al. (eds.): A catalog of the Diptera of America north of
Mexico. United States Department of Agriculture. Agriculture Handbook. No.276. 1696 pp.

Zetterstedt J.W. [1838]. Sectio tertia. Diptera. P. 477-868 in Insecta Lapponica.'1840', Leopold Voss, Lipsiae [= Leipzig], vi + $1140 \mathrm{pp}$.

Zetterstedt J.W. 1846. Diptera Scandinaviae disposita et descripta. Tomus quintus. Ex officina lundbergiana, Lundae [= Lund]. P.1739-2162. 